\title{
From Sociology to Literary Theory
}

The Disciplinary Affiliations of Literature in Section VI of the École pratique des hautes études (EPHE), 1956-1975

De la sociologie aux théories littéraires. Ancrages disciplinaires de la littérature à la VI' section de l'EPHE (1956-1975)

De la sociología a las teorías literarias. Anclajes disciplinarios de la literatura en la sección VI de la Escuela Práctica de Altos Estudios (EPHE), 1956-1975

\section{Lucile Dumont}

Translator. Jean-Yves Bart

\section{OpenEdition}

\section{Journals}

Electronic version

URL: http://journals.openedition.org/bssg/289

DOI: $10.4000 /$ bssg.289

ISSN: 2490-9424

\section{Publisher}

Presses universitaires de Vincennes

Electronic reference

Lucile Dumont, "From Sociology to Literary Theory", Biens Symboliques / Symbolic Goods [Online], 3 |

2018, Online since 15 October 2018, connection on 04 March 2021. URL: http:// journals.openedition.org/bssg/289; DOI: https://doi.org/10.4000/bssg.289 


\section{De la sociologie From Sociology to Literary Theory aux théories littéraires The Disciplinary Affiliations of Literature in Section VI of the École pratique des hautes études (EPHE), 1956-1975}

Ancrages disciplinaires de la littérature à la Vle section de l'EPHE (1956-1975)

Lucile Dumont

traduction | translation

Jean-Yves Bart

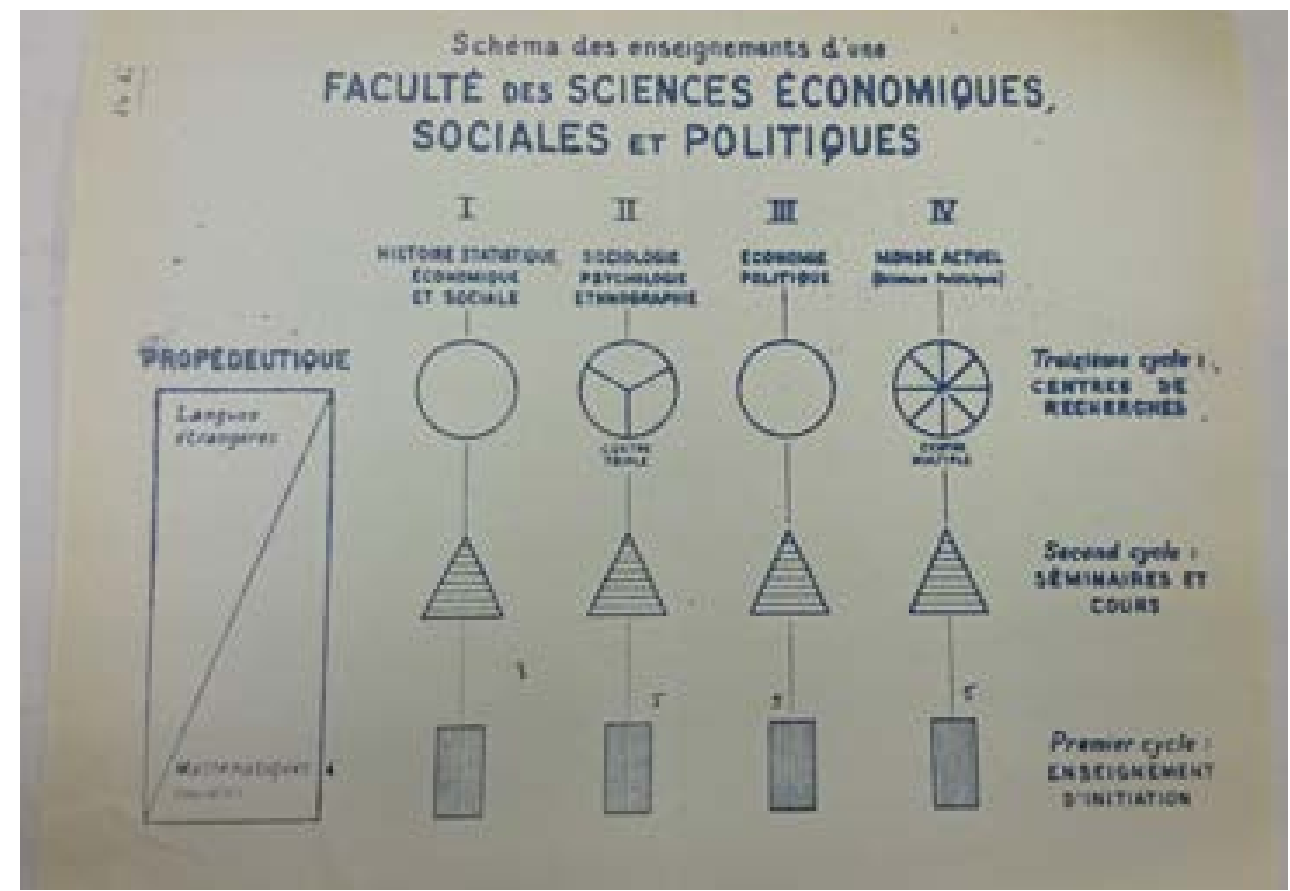

Illustration 1. Un schéma du projet de Fernand Braudel pour la création d'une « Faculté des Sciences économiques, sociales et politiques » / An outline from Fernand Braudel's project for the creation of an "Economic, Social Sciences and Humanities Faculty (Faculté des sciences humaines et sociales)"

Source : Archives de l'EHESS, Fonds Louis Velay, chemise "Projet de création d'une Faculté des sciences humaines et sociales (juin 1958) 》. EHESS Archives, Louis Velay papers, file "Projet de création d'une Faculté des sciences humaines et sociales (juin 1958)". 


\section{Introduction}

Initialement consacrée aux « sciences économiques et sociales", la $\mathrm{VI}$ section de l'École pratique des hautes études (EPHE) est néanmoins bien connue comme l'un des établissements où se pratique la recherche sur la littérature : lieu d'émergence des théories littéraires qui se sont développées dans le sillage du structuralisme, elle est aussi le berceau de plusieurs approches sociologiques de la littérature et des arts ${ }^{1}$. La réception de certains de ces travaux a contribué à rigidifier les oppositions entre ces deux approches, respectivement dites « internes » et « externes », des objets littéraires. Cet article examine l'inscription de l'objet littéraire dans les régimes disciplinaires de la VIe section de l'EPHE afin de comprendre comment les travaux consacrés à la littérature passent, à l'intérieur de l'établissement, de la sociologie aux théories littéraires construites à partir de la linguistique structurale et de la sémiologie. Ce faisant, ils quittent une spécialité - la sociologie de la littérature - située à l'intérieur d'une discipline - la sociologie - en suivant une trajectoire qui s'apparente à une forme de «"régression" vers la pureté professionnelle » (Abbott 2001 : 146). La notion de " régime disciplinaire » nourrit ici une double conception de la « division disciplinaire du travail intellectuel » (Heilbron 2004 ; Lamy \& Saint-Martin 2011). Elle attire l'attention sur le fait que les découpages disciplinaires constituent un instrument privilégié de régulation et de gouvernance des productions intellectuelles et scientifiques. Dans le même temps, elle souligne le caractère temporel des découpages disciplinaires, en rappelant que les disciplines, en tant qu'« unités académiques relativement stables 》 (Convert \& Heilbron 2005), " cadre[s] de perception » courants de l'activité scientifique et " cadre[s] institutionnel[s] "

1 Merci à Jérémy Sinigaglia et Adrien Thibault pour leurs suggestions et leur patience pendant l'élaboration de cet article, à Julien Duval pour sa relecture et à Mathieu Pastor pour son aide et ses conseils.

\section{Introduction}

Although it was initially dedicated to the "Economic and Social Sciences," Section VI (roughly the equivalent of a department) of the École pratique des hautes études (EPHE) is known for being one of the institutions where research on literature was conducted ${ }^{1}$. It was the locus of the emergence of literary theories that developed in the wake of structuralism as well as the cradle of a number of sociological approaches to literature and the arts. The reception of some of these studies has contributed to entrenching the oppositions between the so-called "internal" and "external" approaches to literary works. This article examines how studies on literature fit within the disciplinary regimes of the EPHE's Section VI, in an effort to understand how they shifted from sociology to literary theory based on structural linguistics and semiology. In the process, they left behind a speciality - the sociology of literature-within a discipline - sociology - to instead follow a trajectory that may qualify as a "regression' into professional purity" (Abbott 2001: 146). Here the concept of "disciplinary regime" reflects a twofold approach to the "disciplinary division of intellectual labour" (Heilbron 2004; Lamy \& Saint-Martin 2011). First, it draws attention to the fact that disciplinary divisions are privileged instruments for the regulation and governance of intellectual and scientific output. Second, it emphasizes the temporal nature of these disciplinary divisions, reminding us that disciplines, as "relatively stable academic units" (Convert \& Heilbron 2005), routine "frameworks of perception" of scientific activity and "institutional frameworks" for the organization and reproduction of knowledge (Godechot 2011), are not set in stone.

1 The author wishes to thank Jérémy Sinigaglia, Adrien Thibault, Julien Duval and Mathieu Pastor for patiently proofreading and commenting on several drafts of this paper, as well as Jean-Yves Bart for the translation. 
d'organisation et de reproduction du savoir (Godechot 2011), ne vont pas de soi.

La prise en compte de deux échelles d'analyse s'impose pour saisir le déplacement des objets littéraires de la sociologie vers d'autres régimes disciplinaires. L'échelle de l'établissement tout d'abord, dont la " marginalité ", la « situation particulière » et la « spécificité ", sont régulièrement mises en avant, tant par l'institution elle-même que dans la littérature qui lui est consacrée, au détriment parfois de l'examen des continuités entre son évolution et celle du champ académique. L'étude s'étend de 1956, année significativement marquée par le colloque de Caen consacré à l'enseignement et la recherche et pendant laquelle Fernand Braudel prend la direction de la Vle section de l'EPHE, jusqu'à la transformation de cette section en École des hautes études en sciences sociales (EHESS) en 1975. Cette période se caractérise par la croissance des effectifs étudiants et enseignants et par une inscription progressive des enseignements dans le cadre de plusieurs disciplines (disciplinarisation). L'EPHE s'appuie à la fois sur des centres de recherche et sur des séminaires à destination d'étudiants de troisième cycle et de chercheurs et se présente comme un « établissement d'érudition » par opposition aux lieux d'« enseignement pur » (Karady 1976). Les séminaires renseignent les étudiants et contribuent à leur recrutement en affichant un alignement ou un décalage avec les labels disciplinaires en circulation dans le champ académique. On s'appuiera ici en grande partie sur l'étude des intitulés de directions d'études et de séminaires, tels qu'ils sont recensés et résumés dans les Annuaires de la $\mathrm{Vle}$ section, publiés à partir de 1956. Une deuxième échelle d'analyse montre les ajustements de la VIe section avec les transformations des espaces académiques. Les fonds d'archives de l'établissement mobilisés dans cette étude révèlent ainsi la nécessité de replacer la $\mathrm{VI}^{\mathrm{e}}$ section dans le champ académique et
For a better understanding of how studies on literature shifted from sociology to other disciplinary regimes, two levels of analysis need to be considered. The first is that of the school, whose "marginality," "particular circumstances," and "specificity" are regularly highlighted both by the institution itself and in the literature about it, sometimes to the detriment of the consideration of continuity between its evolution and that of the academic field. This study covers a period beginning in 1956, a year marked by the Caen conference on higher education and research and the beginning of Fernand Braudel's stint at the head of Section VI, and ends in 1975, when Section VI became the École des hautes études en sciences sociales (EHESS). This period was characterized by growing numbers of students and teaching staff and the gradual affiliation of classes to a variety of disciplines, a process known as "disciplinarization." The EPHE relied on both research centres and seminars aimed at postgraduate students and researchers, and presented itself as an "erudite institution" as opposed to places for "pure teaching" (Karady 1976). The seminars informed students and contributed to their recruitment, aligning with or straying from the disciplinary labels then circulating in the academic field. This paper draws largely on the study of the titles given to directeurs d'études (Directors of Research) and seminars, listed in Section VI's directories, published in 1956 onwards. The second level of analysis focuses on how Section VI adjusted to the transformation of academic spaces. Drawing on the institution's archives, I show that it is necessary to situate Section VI within the academic field and to note its similarities with other non-university institutions such as the Centre national de la recherche scientifique (CNRS) and the Collège de France, where the titles of positions reflect the current state of members' power relations and professional practices 
de la rapprocher d'autres institutions non universitaires comme le Centre national de la recherche scientifique (CNRS) ou le Collège de France, où les intitulés de chaires relèvent autant de la politique institutionnelle et scientifique que de l'état des rapports de force et des pratiques professionnelles de ses membres (Feuerhahn 2017). Dans le même sens, le développement de spécialités et les regroupements sous la bannière de la sociologie ou autour de la littérature et des arts à la $\mathrm{Vl}^{\mathrm{e}}$ section ne se comprennent que par rapport aux évolutions plus générales de ces disciplines. Enfin, les transformations de l'établissement et du champ académique prennent également sens dans le champ intellectuel, dans lequel la diffusion du structuralisme est inséparable de certaines logiques académiques. L'association de ces échelles d'analyse contribue à expliquer le déplacement des recherches sur la littérature à la $\mathrm{Vl}^{\mathrm{e}}$ section en deux temps : les modalités de leur introduction (1956-1966) puis l'émergence et la distribution de logiques de concurrence et de collaboration autour des objets littéraires (1966-

1975).

\section{1956-1966 : l'introduction des recherches sur la littérature dans les premiers découpages disciplinaires de la $\mathrm{Vl}^{\mathrm{e}}$ section}

\subsection{La Vle section de l'EPHE : distinction académique et} indistinction disciplinaire?

La création de la Vle section de l'EPHE en 1947, dédiée aux sciences économiques et sociales, s'inscrit dans la dynamique de renouvellement des institutions scientifiques et académiques d'après-guerre. C'est notamment sous l'impulsion de Charles Morazé puis de Fernand Braudel et de Lucien Febvre (figures de proue de l'École des Annales), et grâce au soutien financier de fondations philanthropiques nord-américaines qu'elle voit le as much as institutional and scientific policy (Feuerhahn 2017). Likewise, the development of specialities and mergers under the banners of sociology or literature and the arts in Section VI can only be understood in light of broader trends in these disciplines. Lastly, the transformations of the institution and of the academic field also make sense with regard to the broader intellectual field, in which the rise of structuralism went hand in hand with specific academic trends. Combining these two levels of analysis helps to explain the displacement of studies on literature in Section VI in two stages: the modalities of their introduction (1956-1966); and the emergence and distribution of rationales of competition and collaboration around literary topics (1966-1975).

\section{1956-1966: The Introduction of Literary Studies in the First Disciplinary Divisions of Section VI}

\subsection{The EPHE's Section VI: Academic Distinction, Disciplinary Indistinction?}

In 1947, the creation of the EPHE's Section VI, dedicated to economic and social sciences, was part of a broader postwar dynamic of renewal in scientific and academic institutions. Section VI was born at the instigation of such figures as Charles Morazé and then Fernand Braudel and Lucien Febvre (leading names at the Annales School) and thanks to financial backing from North American philanthropic foundations (Mazon 1988). 
jour (Mazon 1988). Fernand Braudel succède à Lucien Febvre à la tête de la section en 1956, et la conserve jusqu'en 1972 Sous la présidence de Fernand Braudel, la section est adossée à l'Association puis la Fondation pour la Maison des sciences de l'homme (FMSH) à partir de 1959. La Maison des sciences de l'homme $(\mathrm{MSH})$ à Paris regroupe enseignements, centres de recherches et bibliothèques à partir de 1970. Enfin, la présidence de Braudel se distingue par la promotion d'initiatives interdisciplinaires, dont les « aires culturelles » qui réunissent des spécialistes issus de différentes disciplines (Popa 2015).

Dans le champ académique français de l'époque, la $\mathrm{Vl}^{\mathrm{e}}$ section est proche du champ intellectuel et rassemble des membres dans l'ensemble moins pourvus de pouvoir temporel que leurs collègues situés au pôle temporellement dominant du champ académique (Bourdieu 1984). Dans les domaines littéraires, elle compte peu d'agrégés ${ }^{2}$, elle est ancrée dans des réseaux internationaux plutôt que dirigée vers des instances nationales, s'appuie sur un corps enseignant d'origine sociale plus modeste, et elle promeut les nouvelles disciplines plutôt que les humanités classiques. Non soumise à l'impératif de collation des grades ${ }^{3}$, elle ne décerne au départ que le diplôme de l'EPHE. L'institution du doctorat de $3^{\mathrm{e}}$ cycle pour les lettres en 1958 renforce son attrait et son public. Le fait qu'aucun diplôme ne soit en théorie exigé pour assister aux

2 En France, l'agrégation est un concours de recrutement de professeurs de l'enseignement secondaire ou de l'enseignement supérieur.

3 La « collation des grades » est le procédé selon lequel les diplômes nationaux délivrés par certains établissements d'enseignement supérieur après leur validation par l'État ou ses représentants permettent l'obtention de grades universitaires (aujourd'hui : baccalauréat, licence, master, doctorat) Pour les établissements, la collation des grades impose de respecter les cadres nationaux des formations universitaires et donc d'adapter leurs enseignements.
Fernand Braudel succeeded Lucien Febvre as head of the section in 1956, and kept his post until 1972. Under Braudel's presidency, the section entered into a partnership with the Association, and subsequently the Fondation pour la Maison des sciences de l'homme (FMSH) in 1959. The Maison des sciences de l'homme (MSH) in Paris began hosting classes, research centres, and libraries in 1970. Lastly, Braudel's presidency was distinguished by the promotion of interdisciplinary initiatives, including "cultural areas" (aires culturelles) bringing together specialists from a variety of disciplines (Popa 2015).

In the French academic field, Section VI was close to the intellectual field, and overall its members had less temporal power than their colleagues situated at the temporally dominant pole of the academic field (Bourdieu 1984). In literature-related domains, it included few holders of the agrégation (a highly selective competitive examination for teachers and lecturers), had ties with international networks rather than national bodies, relied on teaching staff from somewhat modest backgrounds, and promoted new disciplines rather than the traditional humanities. As it did not fall under the collation des grades procedure ${ }^{2}$, it initially only awarded the EPHE degree. The introduction of a doctorate in literature in 1958 increased its draw. The fact that theoretically no qualifications were required to attend the seminars and that the degree awarded had little value in the academic market led the institution and its members to stick to distinctive postures in the symbolic struggles that rocked the academic field (Kauppi 1996). The hiring of

2 The collation des grades is the procedure through which the national degrees awarded by some higher education institutions give access to academic degrees after a validation by the state or its representatives (currently baccalauréat, bachelor, master's, $\mathrm{PhD}$ ). The procedure requires institutions to comply with national frameworks for higher education and adjust their courses accordingly. 


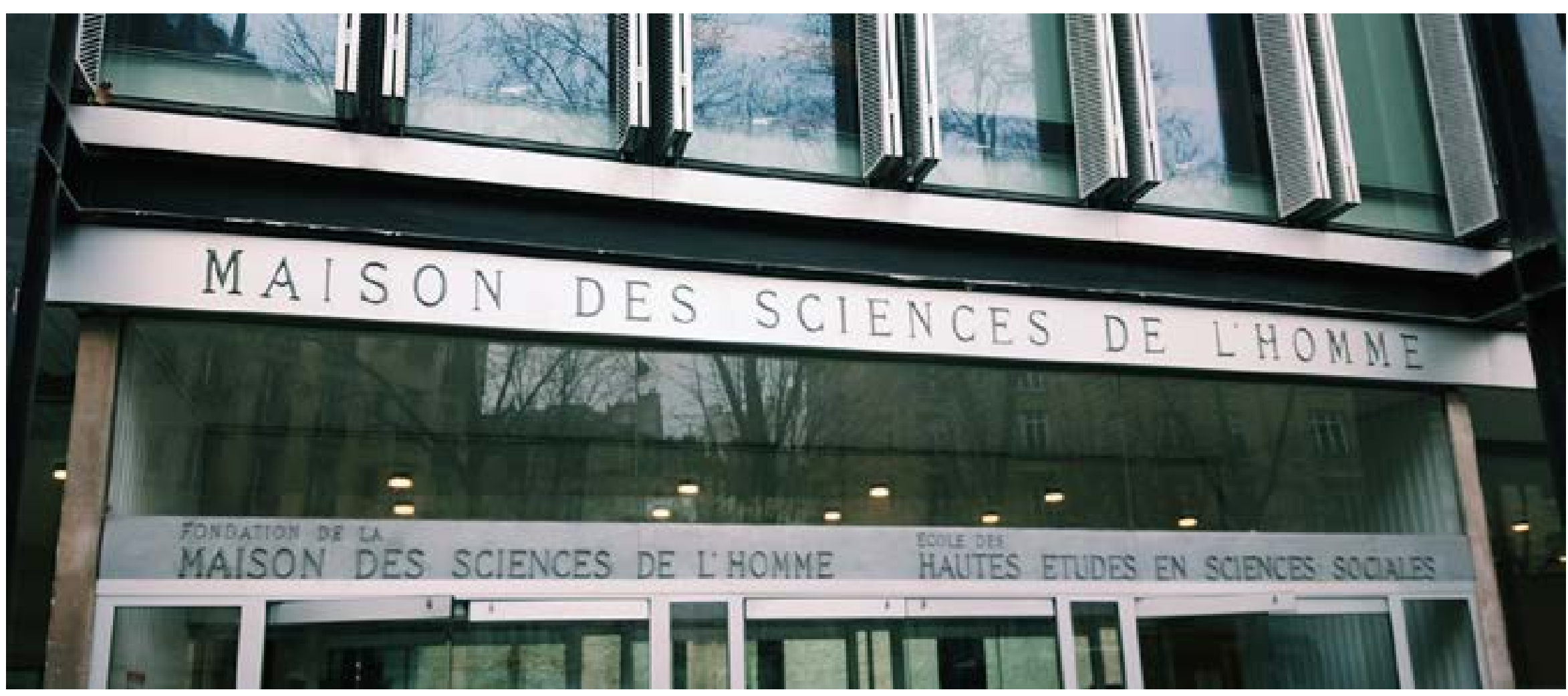

Illustration 2. La Maison des sciences de l'homme au 54, boulevard Raspail à Paris, siège de la Vle section de l'EPHE puis de l'EHESS The Maison des sciences de l'homme at the 54, boulevard Raspail in Paris, which hosted Section VI of the EPHE before it became the EHESS

\author{
Source : Lucile Dumont.
}


séminaires et que le diplôme délivré n'ait que peu de valeur sur le marché universitaire pousse l'établissement et ses membres à se maintenir dans des postures distinctives au sein des luttes symboliques qui animent le champ académique (Kauppi 1996). D'ailleurs, le recrutement des enseignants n'y est pas indexé à des fléchages disciplinaires. Olivier Godechot a montré qu'entre 1960 et 1965 , les invitations des membres de jurys de thèses de $3^{e}$ cycle étaient plus probables de se faire sur la base de la familiarité avec un thème commun, puis sur celle de l'étude d'une " aire culturelle " entre 1966 et 1970, plutôt que sur la base de l'appartenance à une même discipline (Godechot 2011). Pourtant, si l'indistinction disciplinaire est bien à la fois une volonté et un discours d'institution qui s'inscrit dans la démarche de l'École des Annales, certaines dynamiques sociales, organisationnelles et intellectuelles reconduisent des enjeux proprement disciplinaires et inscrivent les transformations de l'établissement dans la continuité de celles de l'enseignement supérieur et de la recherche, interdisant du même coup d'envisager la $\mathrm{Vl}^{\mathrm{e}}$ section comme une institution au-dessus de la mêlée ou totalement " hors du droit commun universitaire "

(Revel \& Wachtel 1996 : 22).

Le premier programme des enseignements de la $\mathrm{Vle}$ section, en 1948, était composé de 29 enseignements répartis en 6 ensembles : "Méthodes », « Orientation et cadres historiques », « Les sociétés humaines ", "Les activités économiques ", "Civilisations et civilisation » et "Semaine d'enquête ». De 1956 jusqu'à l'année académique 1960-1961, d'après les Annuaires, les enseignements ne sont séparés par aucune division disciplinaire. Leur nombre augmente régulièrement pour passer de 41 enseignements en 1956-1957 à 67 en 1960-1961. Ils sont divisés en 3 ensembles à partir de 1960-1961 : "Sciences historiques », "Sciences économiques » et «Sociologie et ethnologie ". Le groupe "Sociologie et ethnologie » dispose du plus grand nombre teachers at the school was not tied to disciplinary affiliations. Olivier Godechot has shown that between 1960 and 1965, scholars were likely to be invited to sit on $\mathrm{PhD}$ examination panels based on their familiarity with a common topic, and subsequently with the study of the same "cultural area" between 1966 and 1970, rather than because they belonged to the same discipline (Godechot 2011). Yet, while this disciplinary indistinction was both a deliberate policy and an institutional discourse that reflected the Annales School's approach, a number of social, organizational, and intellectual dynamics manifested distinctly disciplinary rationales and aligned the institution's transformations with those at work in the field of higher education and research, which prevents us from looking at Section VI as an institution above the fray, entirely "outside the scope of the ordinary laws of academia" (Revel \& Wachtel 1996: 22).

In 1948, Section VI's first curriculum consisted of twenty-nine classes divided into six groups: "Methods," "Orientation and Historical Frameworks," "Human Societies," "Economic Activities," "Civilizations and Civilization," and "Survey Week." From 1956 to the 1960-1961 academic year, according to the directories, there were no disciplinary distinctions between courses. The number of courses steadily increased, from forty-one in 1956-1957 to sixty-seven in 1960-1961. They were divided into three clusters from 1960-1961: "Historical Sciences," "Economic Sciences," and "Sociology and Ethnology." The "Sociology and Ethnology" cluster had the most courses (twenty-nine, i.e., 45 per cent), with "Historical Sciences" and "Economic Sciences" tying in second 
d'enseignements $(29$, soit $45 \%)$, suivi par les « Sciences historiques » et les "Sciences économiques » à égalité (17). Ce découpage tripartite reste en vigueur jusqu'à l'année académique 1965-1966 incluse, à quelques modifications près puisque les divisions s'intitulent alors " Histoire et Géographie », "Sciences économiques » et «Sociologie, ethnologie, psychologie sociale ». Le nombre d'enseignements augmente encore régulièrement, mais la part de chaque ensemble reste relativement stable : on passe de 69 enseignements en 1961-1962 à 76 en 1965-1966, la division

"Sociologie, ethnologie, psychologie sociale " se maintenant à 32 enseignements soit $42 \%$ du total.

L'absence initiale de labellisation disciplinaire n'exclut nullement l'usage de référentiels disciplinaires au sein de l'établissement (centres de recherches, directions d'études, séminaires, administration), ne serait-ce que du fait du rôle central joué par les disciplines dans la carrière des enseignants-chercheurs. La nécessité d'ordonner des enseignements dont le nombre avait quasiment doublé en une décennie explique sans doute en partie l'apparition de découpages disciplinaires. Loin d'être le résultat de regroupements " naturels », a fortiori dans une institution revendiquant une démarche intellectuelle appuyée sur l'unité des sciences humaines et sociales, la labellisation disciplinaire des enseignements ne va pas sans luttes de classements parfois révélatrices des hiérarchies qu'elles bousculent ou entérinent.

Ainsi, du moment où des divisions disciplinaires apparaissent, certains enseignements qui échappent à ces labellisations s'adressent ainsi potentiellement à un public indifférencié. Leur augmentation résulte notamment de la croissance combinée de la fréquentation étudiante et du nombre d'enseignements, et leur évolution qualitative révèle le caractère fluctuant du classement des connaissances comme " générales », «transversales » ou place (seventeen). The three-cluster system was used until (and including) the 1965-1966 academic year, with a few changes-by then, the clusters were named "History and Geography," "Economic Sciences," and "Sociology, Ethnology, Social Psychology." The number of courses continued to increase steadily, but the share of each cluster remained fairly stable-from sixty-nine courses in 1961-1962 to seventy-six in 1965-1966, with thirty-two courses for the "Sociology, Ethnology, Social Psychology" cluster; i.e., 42 per cent of all courses.

The initial absence of discipline labels did not mean that disciplinary references were not used at the institution (in research centres, seminars, and by professors and administrative staff), if only because of the key role disciplines played in the careers of lecturerresearchers (enseignants-chercheurs). The need to establish an order between courses, whose number had virtually doubled in a decade, probably partially explains the introduction of disciplinary distinctions. They were far from the result of "natural" groupings, especially considering that the institution defended an intellectual approach that was based on the unity of the human and social sciences, and involved classification struggles that sometimes reflected hierarchies that they would upset or cement.

As soon as these disciplinary distinctions appeared, some courses escaped labelling and were thus potentially geared towards an unspecified audience. Their increase resulted most notably from the combined growth of student attendance and of the number of courses, and their qualitative evolution reveals the shifting nature of the classification of knowledge as "general," "cross-cutting," or "specialized." While there was just one such unlabelled course in 
« spécialisées ». D'un seul enseignement hors division en 19601961, la $\mathrm{VI}^{\mathrm{e}}$ section passe à 7 en 1965-1966 (Tableau 1). Ils témoignent d'un souci pédagogique déjà ancien dans la section ${ }^{4}$ qui se traduit par la volonté de proposer des outils et des méthodes pour l'ensemble des sciences sociales, toujours dans la tradition de l'École des Annales. Les « méthodes mathématiques " s'imposent ainsi dès le départ comme outil privilégié de formalisation, et le séminaire de « Méthode cartographique » de Jacques Bertin passe de la division "Méthodes », à la division « Histoire et Géographie » avant de devenir « Méthodes cartographiques » puis "Sémiologie graphique ". C'est via ce groupe que la sémantique et la sémiologie font une première percée. Les enseignements hors division disparaissent en 1966-1967, au moment où les enseignements sont intégralement répartis en nouvelles divisions disciplinaires (voir Tableau 4). Certains enseignements hors-division réapparaissent au début des années 1970 sous le label « Méthodes et techniques des sciences sociales ».

$4 \quad$ Voir par exemple le projet de Fernand Braudel pour la création d'une «Faculté des Sciences économiques, sociales et politiques ». Archives de I'EHESS, Fonds Louis Velay, chemise « Projet de création d'une Faculté des sciences humaines et sociales (juin 1958) ». Sur l'échec de ce projet et l'investissement consécutif dans la MSH, voir Mazon 1988.
Section VI in 1960-1961, there were seven in 1965-1966 (Table 1). They reflected the section's longstanding concern ${ }^{3}$ to offer tools and methods applying to all social science in the tradition of the Annales School. "Mathematical methods" quickly prevailed as a tool of choice for formalization; Jacques Bertin's "Cartography Method" seminar moved from "Methods" to "History and Geography," and went on to be renamed "Cartography Methods" and then "Semiology of Graphics." Semantics and semiology made an initial breakthrough in this cluster. Unlabelled courses disappeared in 1966-1967, as all courses were given new disciplinary affiliations (see Table 4). Some courses with no specified disciplinary affiliation reappeared in the early 1970s under the umbrella name of "Social Science Methods and Techniques."
3 See for instance Fernand Braudel's project of creating a "Faculty of economic, social and political sciences." EHESS archives, Louis Velay papers, file "Projet de création d'une Faculté des sciences humaines et sociales (juin 1958)." On that project's failure and the subsequent investment into the MSH, see Mazon 1988. 


\section{Tableau 1}

Les enseignements hors divisions disciplinaires à la Vle section de l'EPHE entre 19601961 et 1965-1966, et leurs enseignants principaux

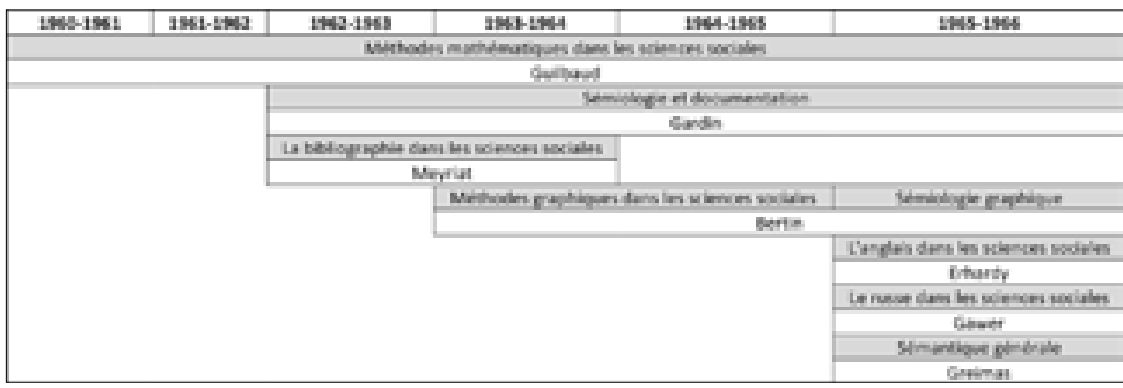

Source : Annuaires de la Vle section.

Leur éclipse au milieu des années 1960 est une des conséquences du double mouvement de disciplinarisation et de contestation des frontières disciplinaires ainsi que de la prise d'importance des questions pédagogiques. Ces transformations ne sont pas spécifiques à l'établissement mais y apparaissent au contraire comme l'une des modalités de " réfraction " (Bourdieu 1991) des injonctions auxquelles est soumis, au même moment, le champ académique (Cardon-Quint 2015, Chevalier \& Encrevé 2006, Drouard 1982, Hauchecorne 2016, Soulié 2012). Ainsi, la réforme Fouchet $^{5}$ en 1966 pousse à une extrême spécialisation disciplinaire, et la loi Faure ${ }^{6}$, deux ans plus tard, entend créer les

5 En supprimant la propédeutique, la réforme Fouchet fait entrer les fléchages disciplinaires plus tôt dans le parcours des étudiants à l'université. Entre autres modifications de l'enseignement supérieur, elle crée les IUT, met en place le DEUG et l'alternative licence/maîtrise dans le deuxième cycle. Voir le décret $n^{\circ} 66-412$ du 22 juin 1966.

6 La loi d'orientation de l'enseignement supérieur ou loi Edgar Faure réform la structure administrative des universités (représentativité dans certaines instances décisionnelles, autonomie financière, statuts d'établissement et
Table 1

Unlabelled courses at Section VI of the EPHE between 1960-1961 and 1965-1966, and their lead professors

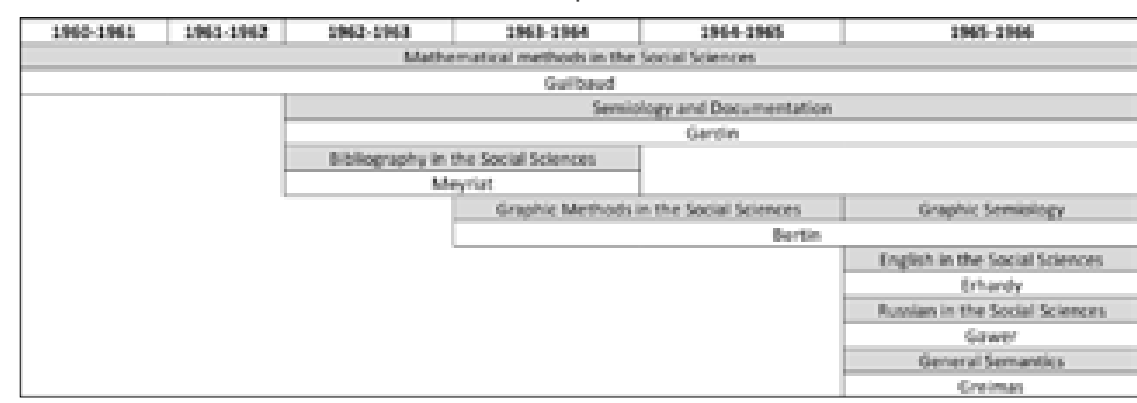

Source: Section VI directories.

The disappearance of courses without a specified affiliation to a discipline in the mid-1960s was one of the consequences of a double trend towards disciplinarization and the reconsideration of disciplinary boundaries and the rising importance attributed to pedagogical matters. These transformations were not specific to the institution; on the contrary, they appear to have been one of the ways in which the demands placed on the academic field (CardonQuint 2015; Chevalier \& Encrevé 2006; Drouard 1982; Hauchecorne 2016; Soulié 2012) were "refracted" (Bourdieu 1991). The socalled "Fouchet reform" of 1966 promoted extreme disciplinary specialization; two years later, the "Faure act5" was intended to

4 Fouchet's reform terminated preparatory courses and introduced discipline distinctions at an earlier stage of higher education. Among other changes, it created the University Institutes of Technology (IUT), the DEUG (General Academic Studies Degree, first two years) and the licence/maitrise alternative at graduate level. See decree no. 66-412 of 22 June 1966.

5 The Higher Education Orientation Act or Faure Act reformed the administrative structure of universities (the representativeness of some decision-making bodies, financial autonomy, the status of the universities and staff) and 
conditions d'une pluridisciplinarité (Dormoy-Rajramanan 2017). Dans ce contexte, la $\mathrm{Vl}^{\mathrm{e}}$ section se place dans un rapport de complémentarité et de distinction avec le CNRS et les universités, avec lesquels elle partage une grande partie de ses membres ${ }^{7}$. L'établissement donne un sens en grande partie pédagogique aux labels disciplinaires. Sa vocation d'enseignement et de recherche et le modèle du séminaire, dont les intitulés et les modalités de classement, au nom de la " recherche de pointe ${ }^{8}$ ", diffèrent des découpages disciplinaires, sont mis en avant contre le modèle du cours magistral universitaire. Plusieurs initiatives pédagogiques pendant cette période reformulent des questions disciplinaires et sont envisagés par rapport aux universités. C'est le cas de la mise en place des Enseignements préparatoires à la recherche approfondie en sciences sociales (EPRASS) à partir de 1965 et du Diplôme d'études approfondies en sciences sociales (DEASS) sur le modèle des Diplômes d'études approfondies (DEA) alors en place dans les facultés de sciences. L'EPRASS est présenté comme une formation sans équivalent dans les facultés de lettres ${ }^{9}$,

des personnels) et remplace les facultés par les UER (Unités d'Enseignement et de Recherche). Voir la loi $n^{\circ} 68-978$ du 12 novembre 1968

7 Les directeurs d'études (DE) « non-cumulants ", c'est-à-dire ceux qui enseignaient à titre principal à la $\mathrm{Vl}^{\mathrm{e}}$ section, ne composaient au départ qu'un tiers du corps enseignant de l'établissement, les deux tiers restants étant composés de DE « cumulants ", c'est-à-dire employés à titre principal dans une autre institution - le CNRS en particulier - et n'enseignant à la $\mathrm{Vl}^{\mathrm{e}}$ section qu'en plus de cette activité (Heilbron 2015 : 150). D'après le «Projet de revalorisation de la carrière des directeurs d'études non cumulants à l'École Pratique des Hautes Études », les DE «non cumulants » composaient quasiment la moitié de l'effectif total de la $\mathrm{Vle}$ section au $1^{\text {er juin }}$ 1966. Archives de l'EHESS, fonds Louis Velay, chemise « Position de l'école dans la recherche » (1966). Voir aussi Revel \& Wachtel $1996: 22$.

8 Archives de l'EHESS, Fonds Louis Velay, chemise « Rapport Roncayolo (novembre 1968) 》.

9 Archives de l'EHESS, Fonds Louis Velay, chemise « EPRASS - Historique et finalités (1968)». establish the conditions for pluridisciplinarity (Dormoy-Rajramanan 2017). Section VI responded by establishing a relationship of complementarity and distinction with the CNRS and the universities, with whom it shared many members ${ }^{6}$. The school gave a largely pedagogical meaning to its discipline labels. It strongly affirmed its vocation for teaching and research and the seminar model, whose titles and modes of classification differed from the disciplinary distinctions in the name of "cutting-edge research"," in contrast to the lecture-based form of teaching that prevailed in universities. During that period, several pedagogical initiatives reformulated disciplinary questions and were approached in light of what the universities were doing. These included the introduction of preparatory courses for advanced social science research (EPRASS) in 1965 and of the advanced social science studies degree (DEASS), modelled on the advanced studies degree (DEA ${ }^{8}$ ) offered by science faculties. The EPRASS was presented as a course that was unavailable at humanities faculties ${ }^{9}$, in disciplines that were seldom or not at all

replaced faculties with UERs (Teaching and Research Units. See act no. 68978 of 12 November 1968

6 The so-called "non cumulative" directeurs d'études (DEs), meaning those who mainly taught in Section $\mathrm{VI}$-especially at the CNRS - , initially made up a third of the institution's teaching staff; the two remaining thirds were "cumulative" DEs, principally employed by another institution and only teaching at Section $\mathrm{VI}$ as a supplement to their main activity (Heilbron 2015: 150). According to the "Project for enhancing the careers of non-cumulating directeurs d'études at the École pratique des hautes études," the "non-cumulative" DEs made up nearly half of the entire Section VI teaching staff as of 1 June 1966. EHESS archives, Louis Velay papers, file "Position de l'école dans la recherche" (1966). See also Revel \& Wachtel 1996: 22.

7 EHESS archives, Louis Velay papers, file "Rapport Roncayolo (novembre 1968)."

8 Master of Advanced Studies.

9 EHESS archives, Louis Velay papers, file "EPRASS-Historique et finalité (1968)." 
dans des disciplines auxquelles les facultés ne forment pas ou très peu (l'anthropologie sociale, la sociologie ou la linguistique).

\subsection{Littérature et philosophie : une entrée par la sociologie}

Jusqu'en 1959-1960, la VI e section ne compte pas d'enseignements spécifiquement consacrés à la littérature. Celle-ci n'est pas pour autant absente de l'établissement, et ne l'a d'ailleurs jamais complètement été : Lucien Febvre ou Roger Bastide avaient par exemple multiplié les invitations à croiser sciences sociales et études littéraires. Le nombre de travaux d'étudiants portant explicitement sur la littérature dans les années 1950 à la $\mathrm{VI}^{\mathrm{e}}$ section est relativement restreint. Georges Balandier et Claude Lévi-Strauss sont ainsi rapporteurs d'un mémoire soutenu en 1956 sur Le théâtre négro-africain et ses fonctions sociologiques, Georges Balandier en dirige un en 1959 sur La littérature douala et sa fonction sociale, Jean-Pierre Vernant un autre en 1960 intitulé Poésie et philosophie dans le Pythagorisme ancien. Le premier enseignement dédié, quoique non exclusivement, à la littérature, fait son entrée à la VI ${ }^{\mathrm{e}}$ section en 1959-1960. II s'agit du séminaire de Lucien Goldmann, "Sociologie de la littérature et de la philosophie », rattaché à la division « Sociologie et ethnologie ». C'est donc par l'approche sociologique des textes littéraires, et en association avec la philosophie, que l'objet littéraire entre officiellement à la $\mathrm{Vle}$ section - et non sous un patronage historique, par opposition aux études littéraires universitaires, structurées sur un modèle chronologique et inspirées par la philologie et le modèle de l'histoire sociale de la littérature élaborée par Gustave Lanson ${ }^{10}$, initialement proche de la sociologie durkheimienne de la fin $\mathrm{XIX}^{\mathrm{e}}$

10 Lanson constitue l'histoire littéraire comme une discipline au sein de la Nouvelle Sorbonne au tournant du $x x^{e}$ siècle. La critique littéraire doit selon lui « restituer l'œuvre dans ses conditions de production, en prenant en compte non seulement l'auteur mais aussi la société de son temps et sa première réception " (Sapiro 2014 : 14). L'importante réception de ce programme et le taught at- universities (such as social anthropology, sociology, and linguistics).

\subsection{A Sociological Pathway into Literature and Philosophy}

Until 1959-1960, there were no courses specifically dedicated to literature in Section VI. Yet literature was not entirely absent, and was never entirely neglected: Lucien Febvre and Roger Bastide, among others, had repeatedly called for social science and literary studies to be combined. In the 1950s, the number of student dissertations explicitly covering literature was fairly small in Section VI. In 1956, Georges Balandier and Claude Lévi-Strauss were the rapporteurs (external examiners) for a dissertation on Black African Theatre and its Sociological Functions; in 1959, Georges Balandier oversaw another on Duala literature and its social function; and in 1960, Jean-Claude Vernant oversaw Poetry and philosophy in ancient Pythagoreanism. Section VI's first course dedicated to literature-albeit not exclusively-was introduced in 1959-1960: Lucien Goldmann's seminar "Sociology of Literature and Philosophy" was classified in the "Sociology and Ethnology" cluster. The sociological approach to literary texts, combined with philosophy, was literature's path towards an official introduction into Section VI-there was no historical patronage, unlike in academic literary studies, which were structured using a chronological model and inspired by philology and the social history of literature developed by Gustave Lanson ${ }^{10}$, who was initially close to late nineteenth-/early twentieth-century Durkheimian sociology

10 Lanson established literary history as a discipline at the Nouvelle Sorbonne at the turn of the twentieth century. In his view, literary criticism needed to "return work to its conditions of production, taking into account not only the author but also the society of the time and the work's initial reception" (Sapiro 2014: 14). This agenda resonated widely, and its promoters rallied around the Revue d'histoire littéraire de la France, founded in 1894, which helped further this approach in teaching. 
début $\mathrm{XX}^{\mathrm{e}}$ siècle (Compagnon 1983, Sapiro 2004). Une partie du séminaire de Lucien Goldmann est consacrée à la sociologie de la littérature tout au long de sa carrière.

Né en 1913 en Roumanie, Lucien Goldmann avait été membre d'organisations de jeunesse communistes avan d'en être définitivement exclu. Après des études de droit, i arrive à Paris en 1934, où il étudie l'économie politique, la philosophie et la littérature. II fuit Paris pendant l'Occupation et se réfugie en Suisse, où il est introduit dans le milieu académique à Zurich par Jean Piaget. Sa thèse d'état, préparée à son retour à Paris lors de son entrée au CNRS après la guerre, est publiée en 1955 chez Gallimard sous le titre Le Dieu caché. Étude sur la vision tragique dans les Pensées de Pascal et dans le théâtre de Racine. Élu directeur d'études (DE) à la $\mathrm{Vl}^{\mathrm{e}}$ section en 1959, il prend la direction du Centre de sociologie de la littérature à Bruxelles en 1964. II se rapproche du Parti socialiste unifié (PSU) au cours des années 1960 et affiche un soutien aux mobilisations étudiantes de 1968. II meurt à Paris en 1970.

Le Dieu caché est le principal succès de Goldmann. II y prône l'association de la "réflexion sur la méthode » et de la « recherche concrète ". Cette dernière n'est toutefois en rien assimilable aux travaux des sociologues contemporains de Goldmann, dont il se distingue par ses objets d'études, ses intérêts théoriques et son opposition à la sociologie empirique ou encore son implication dans la diffusion du structuralisme. II affirme ainsi « refuser le scientisme et [...] préconiser en même temps une science positive, historique et sociologique, des faits humains, opposée à la spéculation et à l'essaysme [sic]. » (Goldmann $1955: 7-8$ ) Le travail

rassemblement de ses promoteurs autour de la Revue d'Histoire Littéraire de la France, fondée en 1894, ont contribué à son succès dans l'enseignement.
(Compagnon 1983; Sapiro 2004). Throughout his career, Lucien Goldmann devoted part of his teaching to the sociology of literature.

Born in Romania in 1913, Lucien Goldmann was a member of Communist youth organizations before being permanently expelled. Having pursued law studies, he came to Paris in 1934, where he studied political economics, philosophy, and literature. He fled Paris during the German occupation and sought shelter in Zurich (Switzerland), where Jean Piaget introduced him to academic circles. He returned to Paris and joined the CNRS after the war. His doctoral thesis was published by Gallimard in 1955 under the title The Hidden God: A Study of Tragic Vision in the Pensées of Pascal and the Tragedies of Racine (English version 1964). $\mathrm{He}$ was elected directeur d'études (DE) in Section VI and 1959 and became the head of the Centre for the Sociology of Literature in Brussels in 1964. He grew closer to the Unified Socialist Party (PSU) during the 1960s and supported the student protests of 1968. He died in Paris in 1970.

The Hidden God was Goldmann's main success. In it he advocated combining "reflection on method" and "practical research." However, the latter in no way resembled the research conducted by sociologists in his day: he had different areas of research and theoretical interests, was opposed to empirical sociology and involved in the diffusion of structuralism. There was "no contradiction," he argued, "between a refusal of 'scientism' and the desire to attain a scientific, historical and sociological knowledge of facts concerning man, a knowledge quite opposed to speculation and belletristic essay writing." (Goldmann 1964 [1955:78]). Inspired by the works of Karl Marx and György Lukács, Goldmann's output displayed a heterodox, anti-Stalianian brand of Marxism, opposed to Althusserianism. Goldmann 
de Goldmann, inspire par la pensée de Karl Marx et de György Lukács, est marqué par un marxisme hétérodoxe, anti-stalinien et opposé à l'althussérisme. Dans ses travaux, Goldmann étudie les « homologies de structure » et introduit un niveau de médiation (la « vision du monde ») entre les groupes sociaux et les œuvres qui le place en rupture avec les théories du reflet. Goldmann applique et discute son « structuralisme génétique » dans ses travaux sur la littérature (Pour une sociologie du roman, 1964 . Structuralisme génétique et création littéraire, 1966) et sur la production culturelle (Structures mentales et création culturelle, 1970).

Deux recrutements contribuent à intégrer davantage l'étude de la littérature au paysage de l'établissement. D'abord celui d'André Miquel qui, né en 1929, est ancien élève de l'École normale supérieure (ENS) Ulm, agrégé de grammaire, docteur ès lettres et spécialiste des textes anciens de géographie arabe. Maître de conférences à la $\mathrm{VI}^{\mathrm{e}}$ section de 1964 à 1967, son séminaire s'intitule "Sociologie de la langue et de la littérature arabes" en 1965-1966, dans la division "Sociologie et ethnologie ". Également traducteur, il devient titulaire de la chaire de langue et littérature arabe du Collège de France au milieu des années 1970. Le deuxième recrutement « littéraire » est celui de Roland Barthes, qui est élu directeur d'études (DE) en 1962 et dont le séminaire s'intitule "Sociologie des signes, symboles et représentations ", toujours dans la division "Sociologie et ethnologie ».

Roland Barthes (1915-1980) grandit dans le Sud de la France puis étudie à Paris et obtient un Diplôme d'études supérieures (DES) de lettres à la Sorbonne en 1939. II ne participe pas à la Seconde Guerre mondiale et entre ensuite dans la vie littéraire parisienne par l'intermédiaire de Maurice Nadeau. Barthes s'est revendiqué tardivement du marxisme studied "structural homologies" and introduced a mediating level ("world vision") between social groups and literary works, which placed him at odds with reflection theories. Goldmann applied and discussed his "genetic structuralism" in his studies on literature (Towards A Sociology of the Novel, 1975 [1964]; Genetic Structuralism and Cultural Creation in the Capitalist World, 2007 [1966]) and on cultural production (Mental Structures and Cultural Creation, 1970).

Two new appointments contributed to furthering the place of literary studies in the institution's landscape. The first was André Miquel, born in 1929, an alumnus of the prestigious École normale supérieure (ENS) of Ulm, holder of the agrégation in grammar, doctor of letters, and a specialist of ancient Arabic geography texts. He was a maître de conférences (lecturer) at Section VI from 1964 to 1967, teaching a seminar entitled "Sociology of the Arabic Language and Literature" in 1965-1966, classified under "Sociology and Ethnology." He was also a translator, and oversaw Arabic language and literature at the Collège de France in the mid1970s. The second "literary" hire was Roland Barthes, who was elected directeur d'études (DE) in 1962 and who taught a seminar entitled "Sociology of Signs, Symbols and Representations," also classified under "Sociology and Ethnology".

Roland Barthes (1915-1980) grew up in the South of France and moved to Paris for his studies. He was awarded a master's (DES) in literature by the Sorbonne in 1939. He was not involved in the Second World War, and was subsequently introduced into Parisian literary life by Maurice Nadeau. Barthes would belatedly call himself a Marxist but 
mais n'a jamais été inscrit au Parti communiste français (PCF). Attaché de recherches au CNRS en sociologie entre 1955 et 1959 (Samoyault 2015 : 289), il obtient son premier poste stable à la $\mathrm{VI}^{\mathrm{e}}$ section, où il est d'abord chef de travaux à partir de 1960. Avec Edgar Morin et Georges Friedmann, Barthes participe à la fondation du Centre d'études des communications de masse (CECMAS) en 1960 et à la création de la revue Communications, un lieu de diffusion de la sémiologie, de la linguistique structurale, des approches structuralistes de la littérature et des arts, et de travaux sur les objets culturels et les médias.

La publication du Degré zéro de l'écriture en 1953 et l'activité de critique littéraire et théâtral de Barthes le font entrer dans les champs intellectuel et littéraire, et le succès des Mythologies en 1957 le fait connaître à un large public. II publie également dans des revues académiques. Dans l'article « Histoire ou littérature ? 》 publié dans les Annales en 1960, Barthes discute Marc Bloch, Lucien Febvre, Lucien Goldmann. Contre le modèle scolaire de l'histoire littéraire, Barthes avance que celle-ci « n'est possible que si elle se fait sociologique, si elle s'intéresse aux activités et aux institutions, non aux individus. » (Barthes 1960 : 185) II met progressivement ce dialogue critique avec les sciences sociales à distance au profit de travaux plus spécifiquement littéraires. La publication de Sur Racine en 1963, la querelle qui suit avec Raymond Picard puis Critique et vérité en 1966 placent Barthes à la tête de la « nouvelle critique », rassemblement hétérogène d'appropriations des méthodes structurales. Les recherches sémiologiques de Barthes sur des objets littéraires $(S / Z, 1970)$ et non littéraires (Système de la mode, 1967) se poursuivent. La diffusion internationale de ses travaux l'intègre ponctuellement à la nébuleuse de la «French Theory ». II est élu au Collège de France en 1977 sur une chaire de «Sémiologie littéraire ». Ses derniers textes témoignent de la place centrale de la littérature dans ses recherches (Fragments d'un discours amoureux, 1977 ; La Préparation du roman, 2003). was never a member of the French Communist Party (PCF). A research associate in sociology at the CNRS between 1955 and 1959 (Samoyault 2015: 289), he obtained his first permanent position at Section VI, which he joined as a chef de travaux in 1960. Alongside Edgar Morin and Georges Friedmann, Barthes participated in the foundation of the Centre for the Study of Mass Communication (CECMAS) in 1960 and in the journal Communications, a vehicle for the diffusion of semiology, structural linguistics, structuralist approaches to literature and the arts, and studies on cultural topics and the media.

With the publication of Writing Degree Zero (1968) [1953] and his activity as a literary and theatre critic, Barthes became a figure of the intellectual and literary field, and the success of his Mythologies (1968)[1957] exposed his work to a wide audience. He also published in academic journals. In a 1960 paper entitled "History or Literature ?," published in the Annales, Barthes discussed the works of Marc Bloch, Lucien Febvre, and Lucien Goldmann. At odds with the model of literary history then prevalent at educational institutions, Barthes argued that literary history "is only possible if it is sociological, and if it is interested in activities and institutions, and not individuals" (Barthes 1960: 185). Barthes gradually moved away from this critical dialogue with social science to focus on more specifically literary endeavours. The publication of On Racine (1992) [1963], the ensuing dispute with Raymond Picard, and Criticism and Truth (1987) [1966] turned Barthes into the leading figure of the "Nouvelle Critique," a label referring to disparate appropriations of structural methods. Barthes continued to conduct semiological studies on literary (S/Z: An Essay, 1975 [1970]) and non-literary objects (The Fashion System, 1967). He was occasionally considered as part of the ill-defined "French Theory" movement abroad. He was elected at the Collège de France in 1977 to oversee "literary semiology." His later work reflects the central place of literature in his research (A Lover's Discourse: Fragments, 1990 [1977]; The Preparation of the Novel, 2011 [2003]). 
Tout en étant le DE le plus proche des espaces littéraires, Barthes ne propose pas au départ de séminaire consacré à la littérature. Jusqu'à la fin des années 1960, on ne fait d'ailleurs pas appel à lui spécialement pour des mémoires ou des thèses portant spécifiquement sur la littérature. C'est également le cas pour Goldmann (Tableau 2). Pour les deux DE, en accord avec les intitulés de leurs directions d'étude, l'objet littéraire n'est ni l'unique objet de leurs travaux, ni le seul support de leurs enseignements.

\section{Tableau 2}

Mémoires et thèses soutenus à la $\mathrm{Vle}$ section entre 1952 et 1966 avec la participation de Goldmann et/ou de R. Barthes dans la direction ou le jury (sur un total de 252 mémoires et 138 thèses de $3^{e}$ cycle soutenus pendant cette période)

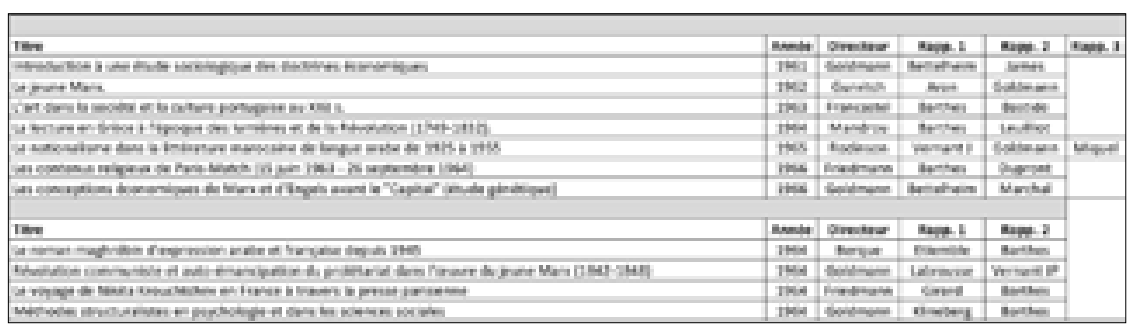

Source : Annuaires de la Vle section

\subsection{La division « Sociologie et ethnologie " et les nouvelles} divisions disciplinaires en 1966-1967

La division "Sociologie et ethnologie ", qui accueille ces spécialistes de la littérature, devient "Sociologie, ethnologie et psychologie sociale » en 1965-1966 (Tableau 3). Les sociologues centraux de l'après-guerre, issus du Centre d'études sociologiques ou proches de celui-ci (Georges Gurvitch, Georges Friedmann, Alain Touraine notamment) y occupent une place importante et font le lien avec la sociologie pratiquée hors de la $\mathrm{Vl}^{\mathrm{e}}$ section. La croissance de la sociologie dans la $\mathrm{Vl}^{\mathrm{e}}$ section relève des
Although he was the DE with the most ties to literary spaces, Barthes initially did not teach a seminar on literature. Until the late 1960s, he was not particularly in demand for master's or PhD dissertations specifically pertaining to literature. The same applied to Goldmann (Table 2). For both DEs, in accordance with the titles of their professorships, literature was neither the sole object of their work nor of their teachings.

Table 2

3rd Cycle and Doctoral Theses at Section VI between 1952 and 1966, with Lucien Goldmann and/or Roland Barthes as Advisors or Committee Members. (out of $2523 \mathrm{rd}$ Cycle dissertations and 138 Doctoral Dissertations defended during this period)

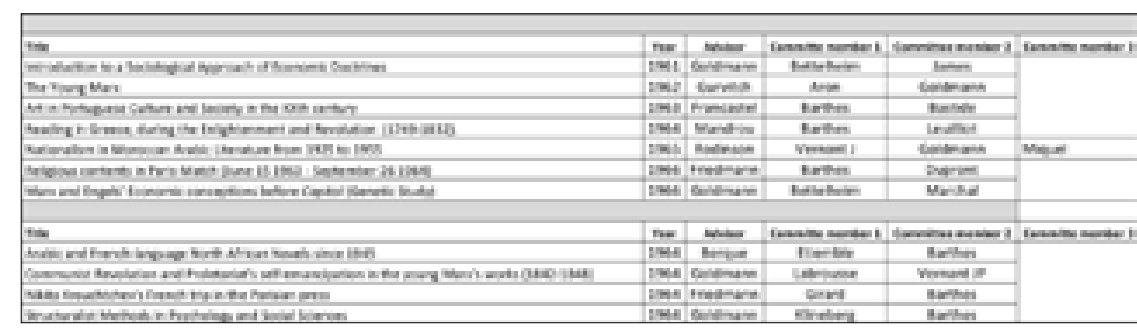

Source: Section VI directories.

\subsection{The "Sociology and Ethnology" Cluster and the New Disciplinary Distinctions of 1966-1967}

The "Sociology and Ethnology" cluster, in which these new specialists of literature were placed, became "Sociology, Ethnology and Social Psychology" in 1965-1966 (Table 3). The most prominent post-war sociologists, who were from or connected to the Centre d'études sociologiques (including Georges Gurvitch, Georges Friedmann, and Alain Touraine), had an important role in it and connected it to the sociological work being conducted outside of Section VI. The rise of sociology in Section VI reflected broader trends within the 
transformations plus générales de la discipline. Alors que jusquelà la sociologie correspondait à un certificat dans le diplôme de philosophie, son institutionnalisation a pérennisé son public dans un cursus universitaire relativement autonome : la licence a été créée en 1958 et les premières thèses sont soutenues au début des années $1960^{11}$. La croissance de la sociologie est également liée à l'expansion universitaire des années 1960 : le nombre de doctorats délivrés augmente à partir du milieu de la décennie, de même que le nombre de chercheurs au CNRS, parmi lesquels le nombre de sociologues passe ensuite de 50 à 130 chercheurs entre 1960 et 1975 (Heilbron 2015 : 152 sq.). Les effectifs de la $\mathrm{Vl}^{\mathrm{e}}$ section augmentent également. La sociologie y acquiert une place de plus en plus centrale et se diversifie en plusieurs programmes théoriques. La montée du structuralisme est un enjeu relativement mineur pour la sociologie, alors qu'elle permet à certaines disciplines, comme la linguistique, de se renouveler et de se structurer sur de nouvelles bases épistémologiques. discipline. While sociology was previously a certificate within the philosophy degree, its institutionalization ensured it lasting student attendance in a relatively autonomous curriculum: the licence (bachelor's) was created in 1958 and the first theses were defended in the early $1960 \mathrm{~s}^{11}$. The growth of sociology was also connected with the expansion of universities in the 1960s: the number of PhDs awarded began increasing by the middle of the decade, and so did the number of CNRS researchers-among whom the number of sociologists rose from 50 to 130 between 1960 and 1975 (Heilbron 2015: 152 sq.). Section VI's staff also expanded. Sociology gained an increasingly prominent place there, branching out into several theoretical programmes. The rise of structuralism was a fairly minor development for sociology, whereas it allowed other disciplines such as linguistics to renew and structure themselves using new epistemological bases.
11 La discipline se développe au cours de cette décennie : la Revue française de sociologie est créée en 1960, l'enseignement de sciences économiques est sociales est introduit dans le secondaire en 1966. Une section «Sociologie et démographie » est créée au Conseil consultatif des universités (CCU, ancêtre du Conseil national des universités ou CNU) en 1969.
11 The discipline grew during that decade: the Revue française de sociologie was created in 1960, and economic and social science classes were introduced into high schools in 1966. A "Sociology and Demography" section was introduced in the Consultative Council of Universities (CCU, the predecessor of today's National Council of Universities, known as CNU) in 1969. 


\section{Tableau 3}

Les enseignements de la division "Sociologie et ethnologie " puis "Sociologie, ethnologie et psychologie sociale » et leurs enseignants, de 1956-1957 à 1965-1966

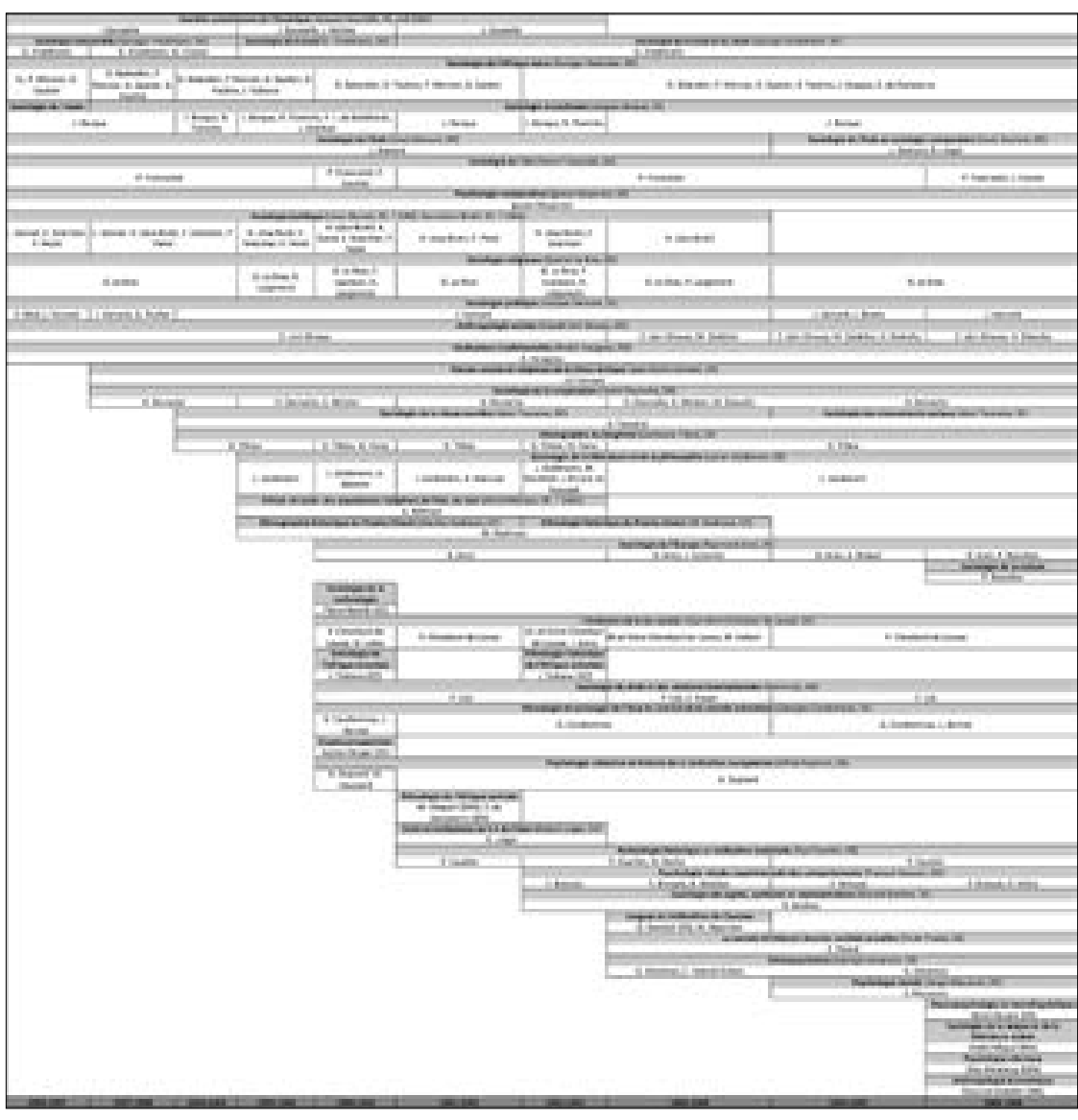

Note : on a relevé tous les enseignements figurant dans les Annuaires, sauf les " conférences complémentaires » et les enseignements " expérimentaux » et " préparatoires », non réguliers, souvent identiques aux enseignements principaux, et dont les comptes rendus ne sont pas systématiques. Voir Annexe.

Source : Annuaires de la Vle section.

\section{Table 3}

Classes in the "Sociology and Ethnology» then "Sociology, Ethnology and Social Psychology» clusters and their lead professors, from 1956-1957 to 1965-1966

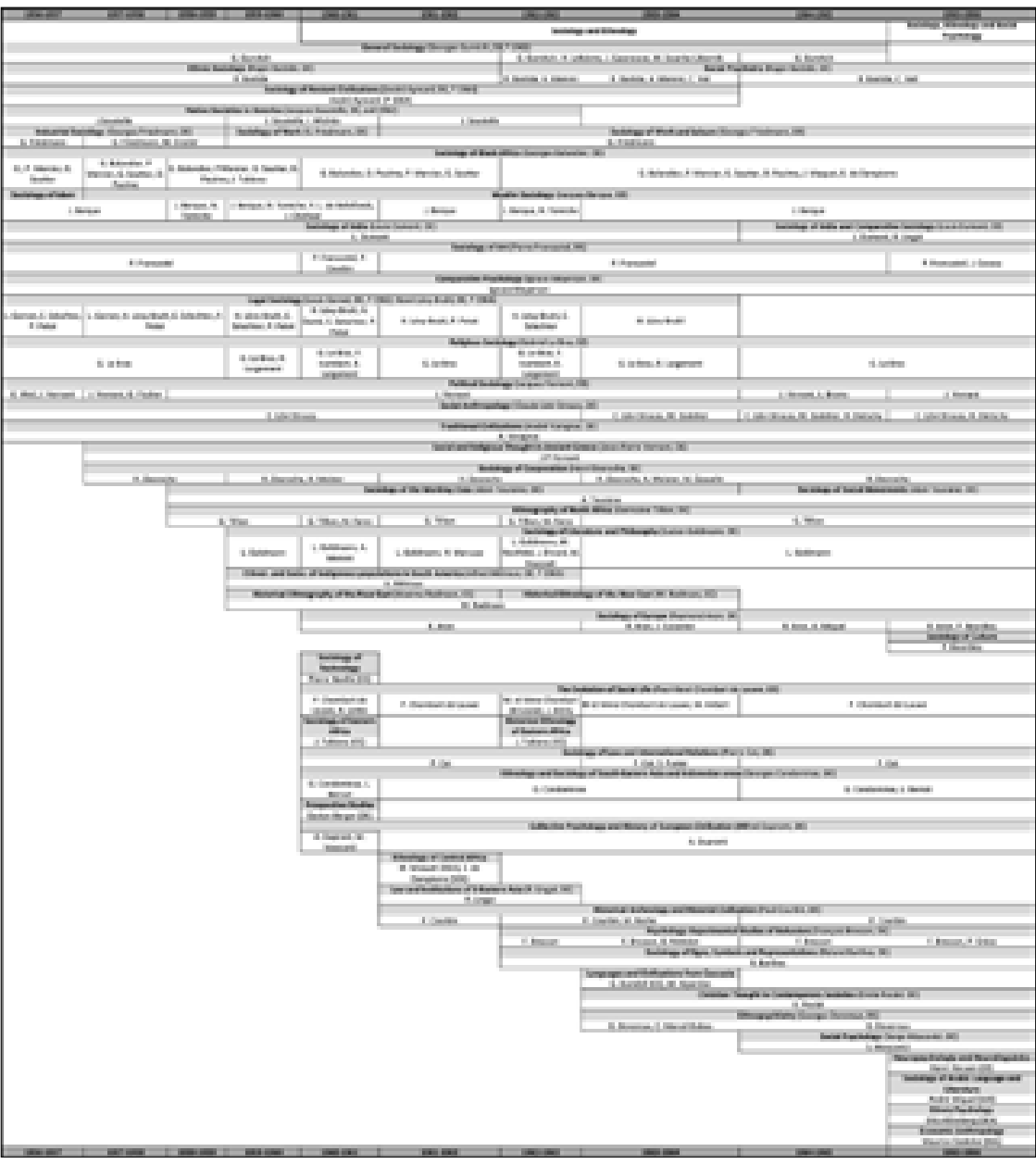

Note: all classes listed in the Annuaires (Directories) are included, except the "Additiona Conferences" (conférences complémentaires) and the "Experimental" and "Preparatory" Classes (enseignements "expérimentaux" et "préparatoires"), not held on a regular basis often identical to main classes and not systematically listed or summarized. See Appendix. Source: Section VI directories. 
Le poids et la diversité de la division "Sociologie et ethnologie " diminuent dans l'offre d'enseignement lorsqu'apparaissent les 12 nouvelles divisions disciplinaires en 1966-1967 (Tableau 4)

Tableau 4

Les nouvelles divisions de la Vle section de l'EPHE en 1966-1967, et le nombre d'enseignements par division

\begin{tabular}{|l|r|}
\hline Intitulé des divisions & $1966-1967$ \\
\hline Histoire & 25 \\
\hline Economie & 19 \\
\hline Sociologie & 13 \\
\hline Sémantique, sémiologie et linguistique & 8 \\
\hline Anthropologie sociale, ethnographic et ethnologie & 5 \\
\hline Psychologie & 5 \\
\hline Géographie & 4 \\
\hline Sciences juridiques et politiques & 3 \\
\hline Démographie & 1 \\
\hline Documentation & 1 \\
\hline Mathématiques sociales & 1 \\
\hline Psychiatrie sociale & 1 \\
\hline Total enseignements & $\mathbf{8 6}$ \\
\hline
\end{tabular}

Source : Annuaires de la Vle section.

Plusieurs facteurs contribuent à expliquer ce nouveau découpage, en premier lieu les transformations du champ académique déjà évoquées. Le lien étroit qui unit la $\mathrm{Vl}^{\mathrm{e}}$ section et le CNRS invite également à prendre en considération la création des laboratoires associés et des équipes de recherches associées en 1966, qui favorisent et à terme institutionnalisent les disciplines et les groupements de spécialistes (Picard 1990). Les membres de la $V l^{\text {e }}$ section expriment par ailleurs leur « souci de mieux se définir par rapport au système universitaire ${ }^{12}$ ” dans le cadre du développement universitaire des sciences sociales, qui fait

12 Archives de l'EHESS, Fonds Louis Velay, chemise « Rapport Roncayolo (novembre 1968) $\gg$
The relative weight and diversity of the "Sociology and Ethnology" cluster decreased in the curriculum when the twelve new discipline subdivisions were introduced in 1966-1967 (Table 4).

Table 4

The new disciplinary subdivisions in the Vlth Section of the EPHE in 1966-1967, and the number of classes per subdivision

\begin{tabular}{|l|r|}
\hline Divisions & $1966-1967$ \\
\hline History & 25 \\
\hline Economy & 19 \\
\hline Sociology & 13 \\
\hline Semantics, Semiology and Linguistics & 8 \\
\hline Social Anthropology, Ethnography and Ethnology & 5 \\
\hline Psychology & 5 \\
\hline Geography & 4 \\
\hline Legal and Political Sciences & 3 \\
\hline Demography & 1 \\
\hline Documentation & 1 \\
\hline Social Mathematics & 1 \\
\hline Social Psychiatry & 1 \\
\hline Total & $\mathbf{8 6}$ \\
\hline
\end{tabular}

Source: Section VI directories.

Several factors go some way towards explaining the new discipline distinctions, starting with the aforementioned transformation of the academic field. Considering the close ties between Section VI and the CNRS, the creation of associate laboratories and research teams in 1966 should also be taken into account, as they favoured and ultimately institutionalized disciplines and groupings of specialists (Picard 1990). The members of Section VI also expressed their "intention to define themselves better in relation to the university system ${ }^{12 "}$ as social science expanded in

12 EHESS archives, Louis Velay papers, file "Rapport Roncayolo (novembre 1968)". 
perdre à l'établissement son quasi-monopole de la formation à ces disciplines, jusque-là délaissées dans les facultés de lettres. L'établissement est enfin contraint de se distinguer des découpages disciplinaires universitaires tout en conservant des labels disciplinaires lisibles et convertibles en ressources dans le champ académique. La répartition des enseignements de "Sociologie et ethnologie " dans les nouvelles divisions suit les pôles thématiques ou méthodologiques qui s'y étaient formés (Figure 1). La sociologie récupère le plus grand nombre d'enseignements (12), la totalité liée à des directions d'étude. Plus de la moitié des $D E$ de sociologie a au moins dix ans d'ancienneté à la $\mathrm{Vl}^{\mathrm{e}}$ section (voir Annexe).

\section{Figure 1}

La répartition des enseignants de la division "Sociologie et ethnologie " vers sept des nouvelles divisions créées en 1966-1967, selon leur ancienneté et la part de directeurs d'études

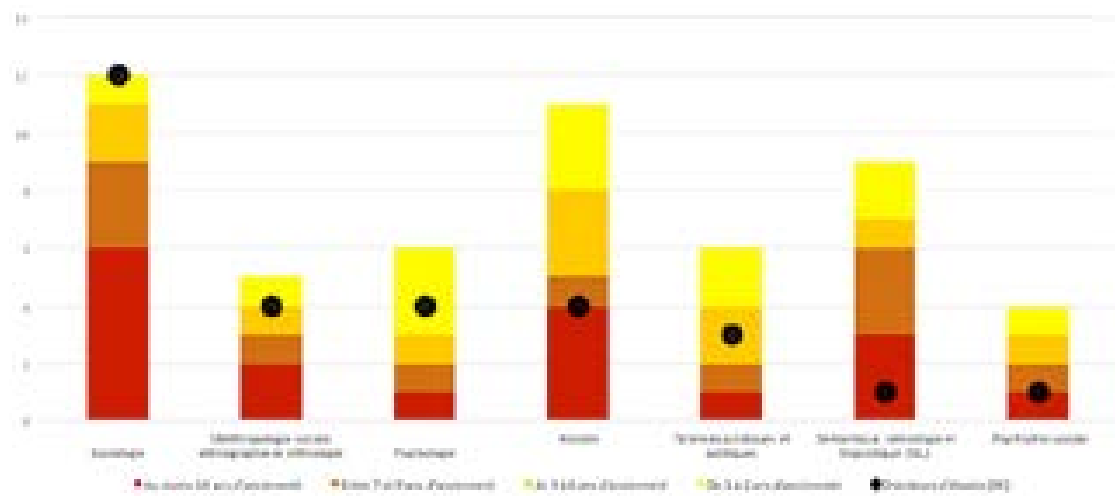

Source: Annuaires de la Vle section de l'EPHE.

Quantitativement, le report des enseignements de « Sociologie et ethnologie " vers des divisions disciplinaires plus fines montre que la sociologie à elle seule ne recouvrait pas entièrement la division universities and the institution lost its virtual monopoly over training in the related disciplines, which had until then been neglected by faculties of literature. Lastly, the school was forced to depart from the universities' discipline labels while retaining clearly defined understanding labels of its own that could be converted into resources in the academic field. The distribution of "Sociology and Ethnology" courses in the new subdivisions followed existing thematic and methodological lines (Figure 1). Sociology secured the highest number of courses (twelve), all connected to directions d'études (Directorates of Research). More than half of the sociology DE had been taught for at least ten years in Section VI (see Appendix).

\section{Figure 1}

Distribution of professors from the Sociology and Ethnology cluster in the seven new subvidisions introduced in 1966-1967, based on the number of years of service in the institution, and the number of Directeurs $d$ Études (Directors of Research)

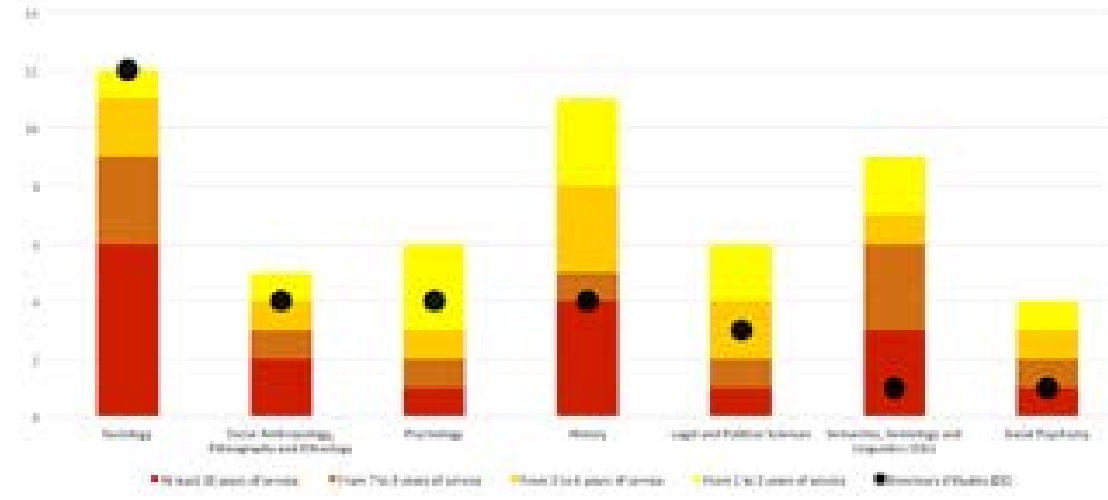

In quantitative terms, the reassignment of "Sociology and Ethnology" classes into finer disciplinary subdivisions showed that sociology alone did not cover the entire "Sociology and Ethnology" 
"Sociologie et ethnologie » mais se présentait plutôt comme un label unifiant la dispersion caractéristique de la "discipline refuge » dans cette période (Bourdieu 1980 : 19 ; 1984 : 159). Les modalités du report montrent ensuite le rôle primordial joué par l'ancienneté et le grade des enseignants dans l'imposition d'une spécialité, d'une division ou d'une discipline. Aucune division n'est en effet dépourvue de $\mathrm{DE}$. Celles qui ne tiennent qu'à un seul enseignement sont le fait d'enseignants anciens dans l'établissement et/ou tenants de position de pouvoir dans le champ académique. Enfin, on observe un morcellement en labels disciplinaires portés par certaines de leurs figures centrales de plusieurs domaines de recherche (Lévi-Strauss pour l'anthropologie, Friedmann, Touraine, entre autres pour la sociologie, Barthes et Greimas pour la sémiologie). Une des nouvelles divisions se distingue dans cette distribution : "Sémantique, sémiologie et linguistique 》(SSL), vers laquelle ne se dirige aucun des membres les plus anciens de "Sociologie et ethnologie ». Sur les trois enseignants de la division qui s'y rattachent, Barthes est le seul DE : André Miquel est maître assistant et Georges Dumézil, professeur au Collège de France, est chargé de conférences extérieur. La division SSL puise donc uniquement parmi les recrues les plus récentes de "Sociologie et ethnologie ». Sa place dans les nouvelles divisions n'est cependant pas négligeable à l'échelle de la $\mathrm{Vl}^{\mathrm{e}}$ section, puisqu'elle est, numériquement, la plus importante après celles d'histoire, d'économie et de sociologie. On y retrouve deux des trois spécialistes de littérature ${ }^{13}$. Pourtant, la division SSL n'est

13 II serait tentant de lire dans la construction de la division SSL, voire dans le développement de la sémiologie, un phénomène d'innovation par " hybridation de rôles ». La sémiologie pourrait en effet être lue, suite au départ de certains de ses promoteurs de la division de " sociologie et ethnologie » vers la division SSL, comme une tentative d' " adapter les méthodes et les techniques de l'ancien rôle aux matériaux du nouveau, dans le but délibéré de créer un nouveau rôle » ( « fitting the methods and techniques of the old role to the materials of the new one, with the deliberate cluster, but rather served as a unifying label masking the scattered nature of the "refuge discipline" at the time (Bourdieu 1980: 19; 1984: 159). The modalities of this reassignment reveal the key role of the teachers' seniority and grade in the imposition of a speciality, subdivision or discipline. Indeed, not a single subdivision was without a DE. Those containing only one course involved longstanding members of the institution and/or holders of positions of power in the academic field. Lastly, disciplines tended to be increasingly divided up between several labels spearheaded by key figures in various research fields (Lévi-Strauss for anthropology; Friedmann and Touraine, among others, for sociology; Barthes and Greimas for semiology). One of the new labels stood out: "Semantics, Semiology and Linguistics" (SSL), in which none of the most senior members of "Sociology and Ethnology" was involved. Out of the three teachers from that cluster active in the new subdivision, Barthes was the only DE: André Miquel was a maître assistant (assistant lecturer) and Georges Dumézil-a professor at the Collège de France-was a chargé de conférences extérieur (guest lecturer). The SSL subdivision featured solely recent recruits of "Sociology and Ethnology." Yet its place among the new subdivisions was notable - in terms of staff size, it came fourth behind history, economics, and sociology. It included two of the three specialists of literature at the school ${ }^{13}$. However, SSL was not the only venue hosting researchers with an interest in literature, since Goldmann remained affiliated with sociology.

13 It would be tempting to see the construction of the SSL subdivision, if not the development of sociology, as a case of innovation through the "hybridization of roles." Indeed, semiology could be read, after some of its promoters in the "Sociology and Ethnology" left for SSL, as an attempt to "[fit] the methods and techniques of the old role to the materials of the new one, with the deliberate purpose of creating a new role" (Ben-David \& Collins 1966: 459). Yet an intrainstitutional interpretation, focused on discipline labels, seems exceedingly limiting in this case. Barthes was only briefly affiliated with sociology and his 
pas l'unique lieu de ralliement des chercheurs intéressés par la littérature, puisque Goldmann reste inscrit en sociologie.

\section{1966-1975 : collaborations et concurrences autour de la littérature}

\subsection{La constitution d'un réseau consacré aux objets} littéraires et artistiques

L'apparition d'un réseau de spécialistes des objets littéraires et artistiques contribue à la formation de groupements disciplinaires et de spécialités. Gaëtan Picon, dont le séminaire « Histoire de la conscience et des objets littéraires " démarre à la $\mathrm{Vle}$ section en 1966-1967, est ainsi rattaché à la division d'histoire.

L'opposition de Gaëtan Picon (1915-1976) à certaines avant-gardes théoriques a sans doute contribué à occulter son rôle dans l'historiographie de la vie intellectuelle des années 1960, pendant lesquelles il se trouvait pourtant à l'interface entre champ littéraire, champ artistique et champ académique. Né dans une famille d'industriels bordelais, agrégé de philosophie, militant des jeunesses socialistes et du Front populaire, Picon, élève de Gurvitch, était proche d'André Malraux qui l'a nommé directeur général des arts et des lettres en 1959, carrière politique à laquelle il a mis

purpose of creating a new role », Ben-David \& Collins 1966 : 459). Pourtant la lecture intra-institutionnelle et focalisée sur les labels disciplinaires semble ici atteindre ses limites. En effet, Barthes n'est que ponctuellement inscrit en sociologie et sa sémiologie se nourrit de l'histoire des mentalités plutôt que de travaux sociologiques. Les chercheurs qui le rejoignent dans la division SSL sont issus d'autres disciplines (linguistique, études littéraires). II faut ainsi nuancer l'idée du passage d'une discipline à une autre puisque ce sont plusieurs traditions et méthodes disciplinaires qui sont reformulées dans la sémiologie.

\section{1966-1975: Collaborations and Competition Around Literature}

\subsection{The Emergence of a Network Devoted to Literary and} Artistic Themes

The emergence of a network of scholars specialized in literary and artistic themes contributed to the formation of disciplinary groupings and speciality. Gaëtan Picon, whose seminar on the "History of Conscience and Literary Objects" began in 1966-1967 at Section VI, was affiliated to the history subdivision.

Gaëtan Picon (1915-1976)'s opposition to the theoretical avant-garde was probably one of the reasons why his role was overlooked in the historiography of 1960 s intellectual life, although during that time he was situated at the intersection of the literary, artistic, and academic fields. Born into a family of Bordeaux industrialists, a holder of the agrégation ${ }^{14}$ in philosophy, an activist in the socialist youth movement and in the Popular Front, Picon, a former student of Gurvitch, was close to André Malraux, who appointed him as directorgeneral of arts and letters in 1959. He ended his political career in 1966-the year he was elected as DE in Section VI with Goldmann's and Lévi-Strauss' support. He began teaching at the Paris school of fine arts and pursued a parallel

semiology drew from the history of mentalities rather than from sociological works. The researchers who joined him in SSL came from other disciplines (linguistics, literary studies, etc.). The idea of a shift from one discipline to another deserves nuancing, as several disciplinary traditions and methods were reformulated in semiology.

14 Higher-level competitive examinations for teachers and professors. 
un terme en 1966 avant d'être élu DE la même année à la $\mathrm{VI}^{\mathrm{e}}$ section avec le soutien de Goldmann et Lévi-Strauss et d'enseigner à l'école des Beaux-Arts de Paris, tout en menant une carrière internationale. Officiant dans plusieurs instances éditoriales (Mercure de France, LÉphémère, collection «Les sentiers de la création » chez Skira), il a consacré son travail à la littérature (André Malraux, 1945 Georges Bernanos, 1948 ; Panorama de la nouvelle littérature française, 1950 ; L'Usage de la lecture 19601963) et à la critique d'art (articles, et ouvrages sur Ingres, Picasso, Dubuffet, Cézanne, le surréalisme). Proche de la critique littéraire de l'École de Genève ${ }^{14}$ et des poètes Yves Bonnefoy et André du Bouchet, il a abordé la littérature au prisme d'une réflexion sur la modernité et le sujet créateur. II meurt en 1976 alors qu'il devait prendre la direction de l'Académie de France à Rome (Callu 2011 : 519).

Le résumé du séminaire de Gaëtan Picon en 1966-1967 rapporte un travail sur la narration romanesque et autobiographique dans la première moitié du $\mathrm{XIX} \mathrm{X}^{\mathrm{e}}$ siècle, qui replace le sujet au centre de l'œuvre littéraire. L'année suivante, une réflexion sur « la notion moderne d'art et de littérature ${ }^{15}$ » a été amorcée autour de textes de Baudelaire et de conférences de Jean Starobinski et d'Yves Bonnefoy. Au début des années 1970, Gaëtan Picon propose dans ses enseignements de répondre à des questionnements d'ordre structural par l'analyse historique. Il est alors accompagné de Marc Soriano, agrégé de philosophie, ancien élève de Jean Piaget et

14 Les critiques littéraires Georges Poulet, Jean Starobinksi et Jean-Pierre Richard, et dans une moindre mesure Jean Rousset, Marcel Raymond et Albert Béguin, sont parfois regroupés sous ce label qui renvoie à une alliance de la linguistique structurale, de la phénoménologie et de la psychologie, développée dans des adaptations variées qui mettent l'accent sur la dimension expérimentale de la littérature et son rapport à la conscience.

15 Annuaire 1968-1969: 120. international career. He worked for several publishing outfits (Mercure de France, LÉphémère, Skira's collection « Les Sentiers de la création ») and wrote on literature (André Malraux, 1945; Georges Bernanos, 1948; Panorama de la nouvelle littérature française, 1950; L'Usage de la lecture 1960-1963) and art criticism (including articles and books on Ingres, Picasso, Dubuffet, Cézanne, and surrealism). He was close to the literary criticism of the Geneva School ${ }^{15}$ and to the poets Yves Bonnefoy and André du Bouchet, and approached literature through the perspective of modernity and the subject as creator. He died in 1976 when he was due to become the next director of the Académie de France in Rome (Callu 2011: 519).

The presentation of Gaëtan Picon's 1966-1967 seminar describes an examination of novelistic and autobiographical narration in the first half of the nineteenth century that places the subject at the centre of literary works. The following year, he considered the "modern notion of art and literature ${ }^{16}$ " based on texts by Baudelaire and lectures by Jean Starobinski and Yves Bonnefoy. In the early 1970s, Gaëtan Picon's teachings proposed a historical approach to structural questions. He then worked alongside Marc Soriano, a holder of the agrégation in philosophy, a former student of Jean Piaget and the author of a PhD thesis on Charles Perrault's fairy

15 The literary critics Georges Poulet, Jean Starobinksi, and Jean-Pierre Richard, and to a lesser extent Jean Rousset, Marcel Raymond and Albert Béguin, were sometimes collectively described by that label, which referred to a variety of adaptations of a mix of structural linguistics, phenomenology, and psychology, emphasizing the experimental dimension of literature and its relation to consciousness.

16 Annuaire 1968-1969: 120. 
auteur d'une thèse sur les Contes de Perrault. Dans les jurys de mémoire et de thèses de $3^{e}$ cycle, Gaëtan Picon est le plus souvent associé à Pierre Francastel, le spécialiste de la sociologie de l'art ; à Jean Cassou, qui anime le séminaire de cette spécialité avec Pierre Francastel à partir de 1965-1966 avant d'avoir son propre séminaire intitulé "Conditions sociales et esprit du surréalisme " à partir de 1968-1969 ; à Barthes et à Goldmann. Un mémoire sur Marc Chagall dirigé par Jean Cassou en 1968 est évalué par Gaëtan Picon et Pierre Francastel ; un autre sur « l'écriture et la peinture » également dirigé par Jean Cassou en 1969 est évalué par Gaëtan Picon et Roland Barthes. La même année, Cassou et Picon évaluent un mémoire sur l'existentialisme et le marxisme chez Paul Nizan dirigé par Goldmann, et un autre mémoire sur Franz Kafka, dirigé par Barthes, est évalué par Picon et Algirdas Julien Greimas. Leur rassemblement dans les instances d'évaluation des travaux d'étudiants illustre plusieurs évolutions : la constitution d'un réseau de spécialistes des objets littéraires et artistiques qui dépasse les nouvelles divisions disciplinaires, l'augmentation du nombre de travaux sur des objets littéraires et artistiques et la diversification des approches, mais aussi la relative rareté des spécialistes de ces objets dans l'établissement, qui les amène à collaborer en dépit d'approches et d'ancrages disciplinaires différents.

Parmi les enseignants qui apparaissent dans ce réseau, on trouve également deux sociologues, Georges Friedmann et Pierre Bourdieu. Friedmann, qui a alors une position centrale dans la sociologie et dont la direction d'études "Sociologie du travail » ne devient pas indifféremment "Sociologie du travail et du loisir " en 1961-1962, encadre ainsi avec Barthes, jusqu'au début des années 1970 des travaux portant sur la culture de masse, la presse, les médias. II dirige alors un mémoire sur le " milieu des poètes dans la société québécoise ", et s'entoure de Jean Cassou et de Jacques Berque dans le jury. Ces collaborations font écho tales. On examination panels for master's and doctoral theses, Gaëtan Picon often sat with Pierre Francastel, specialist in the sociology of art, Jean Cassou, who began co-teaching the seminar for that speciality with Francastel in 1965-1966 and went on to teach his own seminar on "Social Conditions and the Spirit of Surrealism" in 1968-1969, and Barthes and Goldmann. Picon evaluated a dissertation on Marc Chagall supervised by Jean Cassou in 1968 alongside Francastel, and one on "writing and painting" also supervised by Cassou, in 1969, with Barthes. The same year, Cassou and Picon evaluated a dissertation on existentialism and Marxism in Paul Nizan's work, supervised by Goldmann, and Picon and Algirdas Julien Greimas evaluated another on Franz Kafka, supervised by Barthes. Their joint presence on examination panels illustrates several trends, namely: the formation of a network of specialists on literary and artistic themes across the new discipline boundaries; the increasing number of works on literary and artistic themes and the diversification of approaches; as well as the relative scarcity of specialists of literature and art in the institution, leading them to collaborate in spite of their different approaches and discipline affiliations.

The teachers active in that network also included two sociologists: Georges Friedmann and Pierre Bourdieu. Friedmann, then important in French sociology, and whose direction d'études on the "Sociology of Labour" tellingly became the "Sociology of Labour and Leisure" in 1961-1962, teamed up with Barthes to supervise studies on mass culture, the press, and the media until the early 1970s. He then supervised a dissertation on the "poets' circle in Québécois society", with Jean Cassou and Jacques Berque sitting on the examination panel. These collaborations echoed the engagement of Barthes and Friedmann in the CECMAS and 
à l'engagement de Barthes et de Friedmann dans le CECMAS et la revue Communications. Ces objets d'études sont également à I'honneur dans la sociologie de la culture de Pierre Bourdieu. En 1969 , il est rapporteur avec Goldmann d'un mémoire dirigé par Pierre Vilar et intitulé « Lutte des classes et production picturale ». Il apparaît comme troisième rapporteur en 1970 pour un mémoire exécuté sous la direction de Goldmann sur « Madame de Staël et les origines de la sociologie de la littérature en France » aux côtés de Robert Mandrou et de Jean Cassou. Pourtant, à la différence de Goldmann, Bourdieu ne consacre pas son travail uniquement à la littérature mais à la « culture ». En témoignent les résumés de ses premières années de séminaire, et l'évolution de l'objet littéraire dans ses propres travaux.

Le séminaire de sociologie de la culture en 1965-1966 a été consacré aux relations entre « système d'éducation et système de pensée » et à la production, la réception et la diffusion de la «culture » et des œuvres. Sur la littérature, le résumé mentionne un exposé de Jean-Claude Chamboredon sur « les conditions sociales de la création et de la diffusion des œuvres littéraires ». En 1966-1967, le séminaire est consacré à l'« examen critique des travaux ethnologiques et sociologiques consacrés directement ou indirectement à la diffusion culturelle et en particulier de la littérature ${ }^{16}$ », dans le but de " dégager certains des schèmes conceptuels indispensables à une théorie de la diffusion culturelle ${ }^{17}$ ». Les exposés incluent des sujets variés (la santé, l'enseignement, etc.). Les usages du concept de culture en sociologie sont questionnés, notamment à partir des travaux de Raymond Williams. La diffusion et la réception de la culture sont présentées comme l'objet de recherche principal du groupe de chercheurs et des séminaires des années suivantes.

16 Annuaire 1967-1968 : 244-245.

17 Ibid. :245. the journal Communications. Literary and artistic themes were also prominent in Pierre Bourdieu's sociology of culture. In 1969, he was the external examiner for of a dissertation supervised by Pierre Vilar entitled "Class Struggle and Pictorial Output," alongside Goldmann. In 1970, he was the third external examiner for a dissertation supervised by Goldmann on "Madame de Staël and the origins of the sociology of literature in France," alongside Robert Mandrou and Jean Cassou. However, unlike Goldmann, Bourdieu did not focus only on literature - he had a broader interest in "culture," to which the contents of the early years of his seminar and the evolution of literature in his own work attest.

The 1965-1966 seminar on the sociology of culture was devoted to the relations between "systems of education and systems of thought" and the production, reception and diffusion of "culture" and artworks. Regarding literature, the presentation mentions a lecture by Jean-Claude Chamboredon on the "social conditions of the creation and diffusion of literary works." In 1966-1967, the seminar focused on the "critical examination of ethnological and sociological studies pertaining directly or indirectly to the diffusion of culture, and of literature in particular ${ }^{17 "}$ for the purpose of "identifying some of the conceptual schemes that are indispensable for the development of a theory of cultural diffusion ${ }^{18}$." Lectures addressed various topics (health, teaching, etc.). The uses of the concept of culture in sociology were discussed, based in particular on the writings of Raymond Williams. The diffusion and reception of culture was presented as the main research focus of the group of researchers and of the seminars held in the following years.

17 Annuaire 1967-1968: 244-245.

18 Ibid:: 245. 


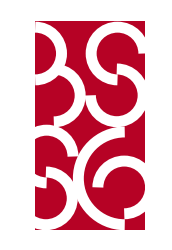

Comme les biens symboliques dans leur ensemble, la littérature occupe très tôt une place privilégiée dans les travaux de Bourdieu, mais elle n'y apparaît comme objet d'enquête spécifique que plus tardivement (Martin 2010). Pourtant, la littérature est dès la fin des années 1960 un terrain plébiscité par Bourdieu pour construire et formaliser la notion de champ, dans des travaux individuels et collectifs (Bourdieu 1966, 1971, 1975 ; Sapiro 2017). La lecture est interrogée comme pratique culturelle dans $\mathrm{La}$ Distinction (1979), et c'est au cours des années 1980 que Bourdieu publie des textes spécifiquement consacrés à la littérature (e.g. Bourdieu 1984, 1985, 1991). Ces différentes recherches aboutissent à la parution des Règles de l'art en 1992. Enfin, les groupes de travail animés par Bourdieu à la $\mathrm{VI}^{\mathrm{e}}$ section puis à l'EHESS mais surtout à l'ENS UIm ont été des lieux de travail et d'enquête collective sur la littérature. C'est d'abord chez les anciens élèves, collègues et membres de ces groupes de travail que s'est appliquée, prolongée et discutée - parfois âprement - l'approche sociologique de la littérature développée par Bourdieu mais également au-delà de ce cercle, avant de connaître une diffusion internationale.

À partir de 1966-1967, la littérature apparaît donc au programme de plusieurs divisions disciplinaires. Ponctuellement associée aux objets artistiques, elle est abordée dans plusieurs cadres théoriques et est envisagée sous les angles de sa production, de sa diffusion et de son interprétation

\subsection{La sociologie de la littérature goldmannienne, une} logique de spécialité

À la Vle section, la sociologie de la littérature goldmannienne ne semble trouver sa place ni en sociologie, ni au pôle qui se constitue autour de la littérature et des arts. Pour comprendre les raisons de cette absence d'ancrage disciplinaire, il faut la replacer dans le
Like symbolic goods as a whole, literature had a prominent place in Bourdieu's work at a very early stage, but it only became a distinct obbject of inquiry at a later point (Martin 2010). In the late 1960s, Bourdieu began relying heavily on literature in his effort to construct and formalize the concept of field (Bourdieu 1966, 1971, 1975; Sapiro 2017). Distinction (1979) examined reading as a cultural practice. In the 1980s, Bourdieu's body of writings on literature expanded (e.g., Bourdieu 1984, 1985, 1991), leading up to the publication of Rules of Art in 1992. Lastly, Bourdieu's working groups in Section VI and subsequently at the EHESS and mostly at the ENS UIm were venues for collective research on literature. Before it gained international exposure, the sociological approach to literature developed by Bourdieu, but also beyond his circle, was primarily implemented, complemented, and discussed by former students, colleagues, and members of these working groups.

Beginning in 1966-1967, literature was featured in the curricula in several disciplinary subdivisions. It was occasionally linked to artistic themes, subjected to a variety of theoretical approaches, and addressed in terms of production, diffusion, and interpretation.

\subsection{Goldmann's Sociology of Literature, a Logic of Specialization}

In Section VI, Goldman's sociology of literature appeared not to find a place either in sociology or in the emerging pole of scholarship on literature and the arts. To understand the reasons for this lack of disciplinary affiliation, we need to situate it within the broader 
développement général de la sociologie de la littérature. Celui-ci fait en effet partie d' " un mouvement plus vaste, à savoir l'attention croissante de la sociologie pour les dimensions symboliques de la société. »(Dirkx 2000 : 37). L'émergence de la spécialité est nourrie par la création d'un ministère dédié à la culture en 1959. Les enquêtes sur la photographie et les musées autour de Pierre Bourdieu (1965, 1966), les travaux de Jean Duvignaud sur le théâtre, ceux de Raymonde Moulin sur les marchés de l'art de même que ceux de Pierre Francastel et de son entourage participent de ce mouvement, visible également dans l'importation de travaux étrangers ${ }^{18}$. La sociologie de la littérature est de longue date tiraillée entre deux disciplines qui se sont construites en opposition (Lepenies 1990), " trop "sociologique" pour les littéraires et trop "littéraire" pour les sociologues » (Sapiro 2014). L'instabilité même du label de "sociologie de la littérature ", parfois « sociologie littéraire " (sous la plume de Gustave Lanson, ponctuellement chez Lucien Goldmann et Jean Starobinski) ou " sociologie du fait littéraire » (Escarpit), est un signe fort de sa faible institutionnalisation. La $\mathrm{VI}^{\mathrm{e}}$ section, du fait de sa relative souplesse sur les découpages disciplinaires, apparait comme un lieu privilégié pour son développement. Elle n'échappe pourtant pas totalement aux logiques disciplinaires qui caractérisent la division du travail intellectuel. Dans les années 1960, la sociologie de la littérature s'émancipe des approches historiques (celles de

18 Architecture gothique et pensée scolastique d'Erwin Panofsky et La Culture du pauvre de Richard Hoggart sont respectivement traduits en 1967 et 1970 aux Éditions de Minuit dans la collection « Le sens commun » dirigée par Pierre Bourdieu. Celle-ci a également accueilli des textes et des approches variées de l'étude des arts et de la littérature (le Mahler d'Adorno en 1976), des auteurs centraux pour le développement de la sémiologie et des théories littéraires (Émile Benveniste, Mikhaïl Bakhtine), de même que des auteurs de la division SSL (Oswald Ducrot, Louis Marin) et une Introduction à la sémiologie par Georges Mounin en 1970. development of the sociology of literature, which indeed was part of a "wider movement, namely that of sociology's growing concern for the symbolic dimensions of society" (Dirkx 2000: 37). The emergence of this speciality was encouraged by the creation of a Ministry of Culture in 1959. Studies on photography and museums initiated by Pierre Bourdieu (1965, 1966), Jean Duvignaud's research on theatre, Raymonde Moulin's work on art markets as well as Pierre Francastel and close colleagues contributed to this movement, which also materialized with the importation of foreign works ${ }^{19}$. The sociology of literature had long been torn between two disciplines whose respective developments were at odds (Lepenies 1990) - "too 'sociological' for literature scholars and two 'literary' for sociologists" (Sapiro 2014). The very instability of the "sociology of literature" label, which sometimes became "literary sociology" (a term used in Gustave Lanson's work, and on occasion by Lucien Goldmann and Jean Starobinski) or the "sociology of the literary fact" (Escarpit), is a clear sign of its weak institutionalization. In light of its relative flexibility regarding disciplinary distinctions, Section VI was a favourable venue for its development. Yet it did not entirely escape the disciplinary rationales at work in the division of intellectual labour. In the 1960s, the sociology of literature detached itself from historical approaches (especially those of Gustave Lanson and Lucien Febvre) in several ways. In 1960, Robert Escarpit (1918-2000), who was in charge of comparative literature

19 Erwin Panofsky's Gothic Architecture and Scholasticism and of Richard Hoggart's The Uses of Literacy were respectively published in 1967 and 1970 by Éditions de Minuit, in Pierre Bourdieu's collection "Le sens commun." In the same collection, texts displaying a variety of approaches to the study of literature and the arts were later published (such as Adorno's Mahler in 1976), as well as work by key authors in the development of semiology and literary theories (Émile Benveniste and Mikhail Bakhtin), by others from the SSL subdivision (Oswald Ducrot and Louis Marin), and Georges Mounin's Introduction à la sémiologie (1970). 
Gustave Lanson ou de Lucien Febvre) dans plusieurs directions. Robert Escarpit (1918-2000), titulaire de la chaire de littérature comparée à l'université de Bordeaux depuis 1952 et promoteur d'une sociologie empirique du fait littéraire, crée en 1960 le Centre de sociologie des faits littéraires à Bordeaux. Bénéficiant de financements de l'Unesco, pour lequel il défend ensuite les programmes de développement du livre, l'auteur du premier «Que sais-je ? » sur la sociologie de la littérature (1958) joue un rôle pivot dans le développement initial de la spécialité dans les espaces francophones (Van Nuijs 2007). Enfin, les approches marxistes de la littérature, explorées par Sartre au début des années 1970, sont au cœur des travaux de Goldmann et des promoteurs du marxisme d'inspiration althussérienne, qui discute longuement les dimensions sociales des œuvres littéraires sans pour autant se réclamer de la sociologie.

Dans ses enseignements, Goldmann associe des questions philosophiques et théoriques à des travaux pratiques en sociologie de la littérature (Tableau 5). at the University of Bordeaux and an advocate of an empirical sociology of the "literary fact," created the Centre for the Sociology of Literary Facts in Bordeaux. He received funding from UNESCO, whose book development programmes he then promoted. Having authored the first introduction to the sociology of literature in the famous « Que sais-je ? » collection (1958), he played a key role in the speciality's initial development in French-speaking spaces (Van Nuijs 2007). Lastly, Marxist approaches to literature, which Sartre explored in the early 1970 s, were also key to the work of Goldmann and the promoters of an Althusser-influenced brand of Marxism, who extensively discussed the social dimensions of literary works but did not call themselves sociologists.

In his teaching, Goldmann combined the examination of philosophical and theoretical questions and practical sociology of literature research (Table 5). 


\section{Tableau 5}

Les séminaires de "Sociologie de la littérature et de la philosophie » de Lucien Goldmann puis ceux de «Sociologie de la littérature » de Jacques Leenhardt à la Vle section de

l'EPHE, de l'année académique 1959-1960 à 1975-1976

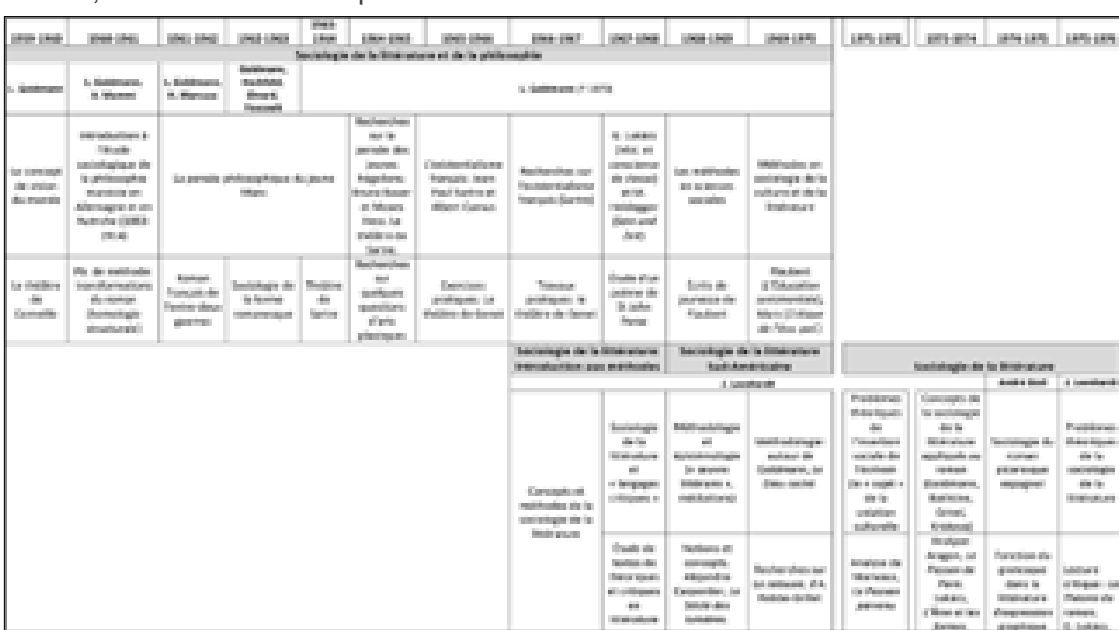

Source : Annuaires de la Vle section de l'EPHE.

Bien que le privilège accordé aux travaux philosophiques ou à ceux portant sur la littérature soit irrégulier, les deux objets sont conservés. Goldmann étudie à la fois des textes classiques et contemporains (Corneille, Malraux, Nizan, Drieu La Rochelle, Sartre et l'existentialisme, Genet). Parmi les invités au séminaire, on peut citer Jean Duvignaud et Henri Lefebvre, marxistes proches de la revue L'homme et la société et également associés au groupe de sociologie de la connaissance, mais aussi Louis Althusser, Theodor Adorno et Herbert Marcuse, le critique Paul Bénichou, l'auteur de Pourquoi la nouvelle critique ?(1966) Serge Doubrovsky, et Roland

\section{Table 5}

Lucien Goldmann's Seminars in "Sociology of Literature and Philosophy" and Jacques eenhardt's Seminars in "Sociology of Literature" at Section VI of the EPHE from 19591960 to $1975-1976$

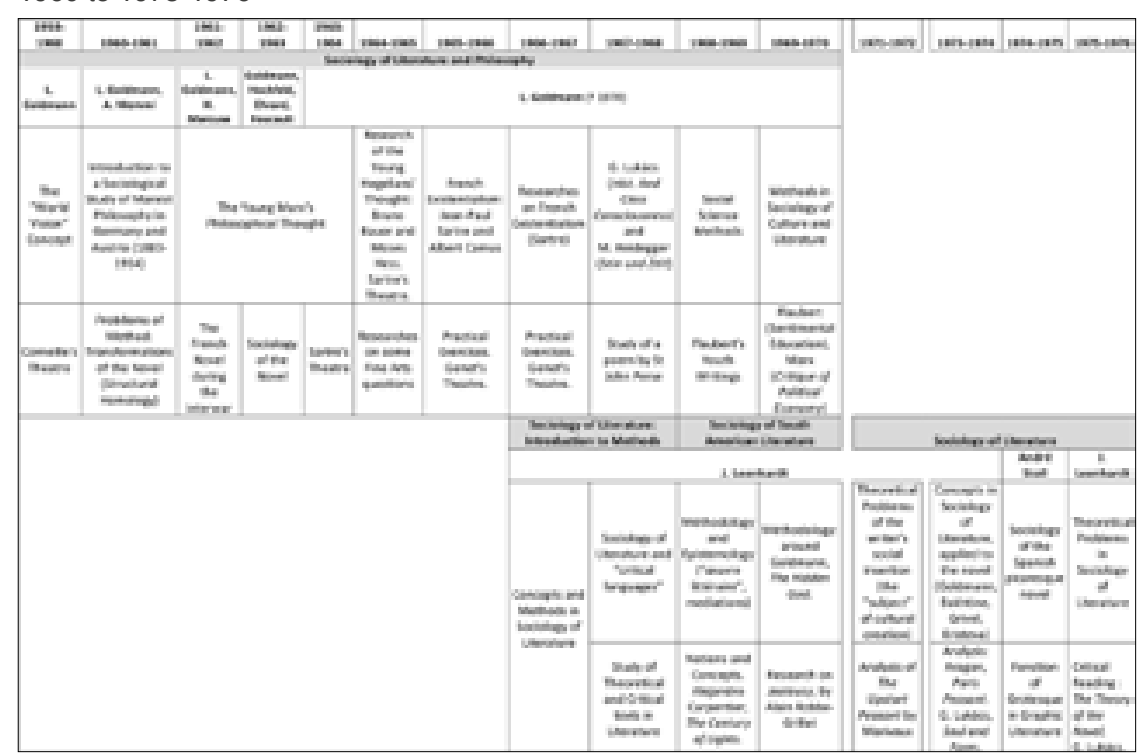

Source: Section VI directories.

Although emphasis was irregularly placed on studies of philosophy and literature, the two areas remained addressed. Goldmann studied both classic and contemporary works (Corneille, Malraux, Nizan, Drieu La Rochelle, Sartre and existentialism, and Genet). Guests at the seminar included Jean Duvignaud and Henri Lefebvre, both Marxists with ties to the journal L'homme et la société and the working group on the sociology of knowledge, as well as Louis Althusser, Theodor Adorno, Herbert Marcuse, critic Paul Bénichou, author of The New Criticism In France, Serge Doubrovsky, and Roland Barthes. Barthes and Goldmann occasionally collaborated 
Barthes. Barthes et Goldmann collaborent ponctuellement jusqu'au milieu des années 1960 : pour l'encadrement d'étudiants, autour d'échanges intellectuels, au moment de la querelle de la " nouvelle critique » et des alliances qu'elle produit, ou encore grâce à leur participation commune à des colloques (sociologie de la littérature

à Bruxelles en mai 1964 par exemple).

D'après les Annuaires, le séminaire de Goldmann compte une quinzaine d'auditeurs réguliers. Parmi ses élèves ayant poursuivi des carrières littéraires, on peut citer le chercheur d'origine tchèque Pierre Václav Zima (1946-), également élève de Jean Cassou, et dont les travaux s'orientent vers la sociocritique et des analyses des théories critiques de la littérature. Deux autres élèves de Goldmann ont par ailleurs joué un rôle de premier plan dans la diffusion des théories littéraires structuralistes et post-structuralistes. II s'agit de Julia Kristeva, universitaire et psychanalyste proche de Barthes et de la revue Tel Quel, et de Sylvère Lotringer, intermédiaire de la «French Theory » dont les relations avec Barthes et Goldmann étaient plus lointaines mais se sont révélées centrales dans sa formation et sa carrière. À partir de 1966-1967, le séminaire de Goldmann se double d'un enseignement de Jacques Leenhardt, son assistant ${ }^{19}$. Leenhardt entend alors « ouvrir le dialogue avec certaines théories dites anhistoriques de la littérature 20 ». II publie sur les rapports entre la sociologie de la littérature et la sémantique structurale, sur le Nouveau Roman contre les travaux du groupe de Tel Quel (Lecture politique du roman, 1973). Son séminaire, qui exclut la philosophie pour se consacrer à la sociologie de la

19 Né à Genève en 1942, ayant également travaillé avec Jean Piaget, Jacques Leenhardt étudie la philosophie puis la sociologie à Paris. II envisage une thèse avec Henri Lefebvre sur la " sociologie de l'invention », puis s'inscrit avec Goldmann et, après le décès de celui-ci, termine sa thèse avec Barthes en 1972.

20 Annuaire 1967-1968: 258. until the mid-1960s: they advised students and pursued intellectual exchanges at the time of the dispute over New Criticism and its resulting alliances, and jointly participated in conferences (such as Brussels 1964 on the sociology of literature).

According to the directories, Goldmann's seminar was regularly attended by around fifteen auditors. Students who went on to pursue literary careers included the Czech-born researcher and scholar Pierre Václav Zima (1946-), who was also a student of Jean Cassou, and who turned to sociological criticism and the analysis of critical theories of literature. Two other students of Goldmann also played a prominent role in the diffusion of structuralist and post-structuralist literary theories: Julia Kristeva, an academic and psychoanalyst with ties to Barthes and the journal Tel Quel, and Sylvère Lotringer, a promoter of French Theory whose more distant relationships with Barthes and Goldmann turned out to be crucial to his training and career. Starting in 1966-1967, Goldmann's seminar was complemented by a class led by his assistant Jacques Leenhardt ${ }^{20}$. Leenhardt hoped to "open up a dialogue with certain so-called a-historical theories of literature ${ }^{21}$." He published research on the relations between the sociology of literature and structural semantics, and on the Nouveau Roman (the new novel), airing views that clashed with those of the $T e l$ Quel group (Lecture politique du roman, 1973). His seminar, which excluded philosophy and focused on the sociology of literature,

20 Born in Geneva in 1942, Jacques Leenhardt had previously worked with Jean Piaget. He studied philosophy and then sociology in Paris. After considering a thesis supervised by Henri Lefebvre on the "sociology of invention," he enrolled on a thesis with Goldmann, which he completed with Barthes in 1972 after Goldmann had passed away.

21 Annuaire 1967-1968: 258. 
littérature, illustre la manière dont la sociologie de la littérature goldmannienne tente de faire sa place dans la critique littéraire. C'est par rapport à la critique littéraire, et non par rapport à la sociologie, que Leenhardt se positionne. II juge nécessaire d' " orienter les étudiants dans les dédales de ce qu'il est convenu d'appeler les "langages critiques" " pour " clarifier avec un maximum de précision les positions théoriques et épistémologiques impliquées dans chacun de ces langages » et trouve dans la sémantique « une importante confirmation d'ordre empirique ${ }^{21}$ » pour la sociologie de

la littérature.

Leenhardt devient maitre de conférences à la VIe section en 1974. II succède à Goldmann, décédé en 1970, à la tête du "Groupe de sociologie de la littérature ", tandis que d'autres élèves de Goldmann poursuivent leurs travaux séparément ${ }^{22}$. Leenhardt hérite d'un public étudiant et d'une petite structure qui comprend un poste de secrétaire, celui de Brigitte Navelet, un poste d'ingénieure de recherche, celui de Martine Burgos, et un bureau rue Monsieur-le-Prince à Paris. Leenhardt est élu DE en 1995, soit plus de vingt ans après être devenu maître de conférences, ce qui entrave ses possibilités de « faire école ". II porte sur sa carrière un regard qui, non sans rappeler la posture de Goldmann, oscille entre revendication d'autonomie et constat d'un certain isolement compensé par les circuits transnationaux de la sociologie de la littérature. Localement, le fait de ne pas être intégré au « 54 », soit la MSH sur le boulevard Raspail, l'a ainsi «marginalisé ${ }^{23}$ » et

21 Annuaire 1968-1969: 320.

22 C'est notamment le cas de Michael Löwy qui aborde la littérature dans plusieurs travaux. II a par ailleurs coécrit avec Sami Naïr une introduction à la pensée de Goldmann (Lucien Goldmann ou la dialectique de la totalité, 1973).

23 Entretien avec Jacques Leenhardt, 5 juillet 2014 illustrated the Goldmannian sociology of literature's attempt to carve a space for itself in literary criticism. Leenhardt positioned himself in relation to literary criticism-not sociology. He believed it necessary to "help students find their way in the maze of what is commonly called 'critical languages"' to "clarify the theoretical and epistemological positions on display in each of these languages as precisely as possible." He found semantics to be a "major empirical confirmation ${ }^{22 "}$ for the sociology of literature.

Leenhardt became a maître de conférences (lecturer) at Section VI in 1974. He succeeded Goldmann, who had died in 1970, as the head of the "Sociology of Literature Group," while other students of Goldmann went separate ways to pursue their research ${ }^{23}$. Leenhardt inherited an audience of students and a small structure that included a secretary (Brigitte Navelet), a research engineer (Martine Burgos), and an office in the rue M. le Prince in Paris. Leenhardt was elected DE in 1995, roughly twenty years after becoming a lecturer, which did not help further his career. His outlook on the latter was reminiscent of Goldmann's-he went back and forth between the assertion of his autonomy and the observation of a sense of isolation, compensated by the transnational circuits of the sociology of literature. Locally, not being a part of the "54" (the MSH on Boulevard Raspail) led to him being "marginalized ${ }^{24 "}$ and to some degree deprived of the institution's "intellectual power ${ }^{25}$," and socialization venues-like Goldmann, who would reportedly

22 Annuaire 1968-1969: 320

23 One was Michael Löwy, who wrote on literature on several occasions. He also co-authored an introduction to Goldmann's thinking alongside Sami Naïr (Lucien Goldmann ou la dialectique de la totalité, 1973).

24 Interview with Jacques Leenhardt, 5 July 2014.

25 Ibid. 
soustrait, dans une certaine mesure, au «pouvoir intellectuel ${ }^{24}$ » et aux instances de socialisation de l'établissement - comme Goldmann, dont il est rapporté qu'il recevait ses étudiants hors de la $\mathrm{VI}^{\mathrm{e}}$ section $^{25}$. Leenhardt rapporte ne pas avoir travaillé avec les sociologues de la $\mathrm{VI}^{\mathrm{e}}$ section, renforçant par là son sentiment de " marginalité » - de nouveau rabattu sur la figure de Goldmann, exilé, immigré, vu comme dépourvu des atouts nécessaires à une insertion réussie dans les espaces académiques parisiens que l'on peut aussi comprendre comme une manière de faire de nécessité (sociale) vertu (scientifique) (Ben-David \& Collins 1966,

$$
\text { Bourdieu } 2001 \text { : 152) }
$$

«Par manque de réseau, par formation intellectuelle, par choix épistémologique de comment aborder un problème, j'étais toujours centrifuge et non pas centripète. Donc de fait voilà. [...] j'ai décidé "restons petits" et ça aussi, si on ajoute ça à toutes les autres raisons d'un certain isolement, un isolement que j'ai toujours au fond trouvé très agréable, mais que donc d'une certaine façon j'ai entretenu ${ }^{26}$. "

La ligne philosophique de Goldmann et la synthèse entre analyse interne et externe de Leenhardt sont en opposition avec la ligne bourdieusienne, qui rencontre un important succès, se diffuse amplement et qui surtout revendique une séparation entre philosophie et sociologie. Dans le même temps, la sociologie de la littérature est contestée par les promoteurs des théories littéraires. Les sociologues de la littérature et, plus généralement, certains défenseurs des approches sociales des textes littéraires, issus des sciences sociales ou des études littéraires francophones, constituent un réseau propre à la spécialité " sociologie de la

24 Ibid.

25 Ibid., et entretien avec Annie Goldmann, 2 novembre 2017, réalisé en collaboration avec Quentin Fondu.

26 Ibid. meet his students outside of Section $\mathrm{VI}^{26}$. Leenhardt says he did not work with the sociologists in Section $\mathrm{VI}$, which further gave him a sense of being "marginal," again bringing him closer to the figure of Goldmann as an exiled immigrant, seen as lacking the resources needed for a successful integration into Parisian academic spaces - a stance that can also be understood as a way of making a (scientific) virtue out of (social) necessity (Ben-David \& Collins 1966, Bourdieu 2001: 152):

"As I didn't have a network, because of my intellectual training, of my epistemological approach to problems, I was always centrifugal-not centripetal. So you know, there it was. [...] I decided 'let's remain small', it added up to all the reasons for the sort of isolation I found myself in, which deep down I always found very pleasing, and which I perpetuated in a certain way ${ }^{27} . "$

Goldmann's philosophical stance and Leenhardt's synthesis between internal and external analysis were at odds with Bourdieu's approach, emphasizing the separation between philosophy and sociology, which was very successful and spread widely. At the same time, the sociology of literature was challenged by the promoters of literary theories. Sociologists of literature, and more broadly advocates of social approaches to literary texts from the French-speaking fields of social science and literary studies, formed a network specific to the "sociology of literature" speciality, which materialized in the form of conferences and occasional

26 Ibid., and Interview with Annie Goldmann, carried out in collaboration with Quentin Fondu, 2 November 2017.

27 Ibid 
littérature ", notamment visible dans l'organisation de colloques et de collaborations ponctuelles. Pour ceux-ci, ce sont le plus souvent les réseaux de cette spécialité qui, dans une certaine mesure, supplantent l'inscription disciplinaire en sociologie et/ou dans les études littéraires. Ce réseau se constitue à l'écart des pôles dominants du champ académique (Hauchecorne 2011), tant au niveau national (Bordeaux, Lille, puis Vincennes) que transnational. La sociocritique et la sociologie de la littérature belge et québécoise, plutôt ancrées dans des disciplines littéraires, y constituent ainsi des interlocuteurs privilégiés. En d'autres termes, c'est le plus souvent au-delà des frontières de la sociologie d'une part, et au-delà des frontières nationales d'autre part, que se constitue et se consolide ce réseau. De même, le public étudiant de Leenhardt, comme celui de Goldmann, est international. La carrière de Leenhardt va également dans ce sens : il est en lien avec la Belgique, où Goldmann avait dirigé le Centre de sociologie de la littérature, travaille en Hongrie, aux Etats-Unis et en Amérique latine, où un projet d'installation d'un centre de recherches sur la sociologie de la littérature amorcé avec l'Unesco échoue par deux fois. Enfin, le marxisme de Goldmann avait été éclipsé à la fin des années 1960 par d'autres hétérodoxies, principalement les approches althussériennes et le maoïsme (Matonti 2005). Le succès des théories littéraires, alliées à ces mouvements, a participé au maintien à l'écart de la sociologie de la littérature goldmannienne, renforcé dans les années suivantes par le reflux des approches marxistes.

\subsection{Le pôle « littéraire " de la $\mathrm{Vl}^{\mathrm{e}}$ section}

La division SSL grandit entre 1966 et le milieu des années 1970. Les collaborations entre Barthes et Goldmann déclinent définitivement au profit de collaborations plus fréquentes entre Barthes et Greimas. En 1966-1967, la division SSL se compose collaborations. For them, this network tended to take precedence over their affiliation to sociology and/or literary studies. The network was formed at a distance from the dominant poles in the academic field (Hauchecorne 2011), both at the domestic (Bordeaux, Lille, then Vincennes) and the transnational level. Belgian and Québécois scholars in sociological criticism and the sociology of literature, whose roots lay mostly in literary disciplines, were partners of choice. In other words, this network mostly grew beyond disciplinary and national boundaries. Likewise, Leenhardt's students, like Goldmann's, were from different countries. Leenhardt's career was similarly international: he had ties to Belgium, where Goldmann had directed the Centre for the Sociology of Literature, Hungary, the USA, and Latin America, where plans to set up a centre for research on the sociology of literature failed twice. Lastly, by the late 1960s, Goldmann's Marxism had been overshadowed by other heterodox approaches, mainly Althusserian approaches and Maoism (Matonti 2005). The combination of the success of literary theories and of these movements led Goldmann's sociology of literature to be further marginalized-a process amplified in the following years by the decline of Marxist approaches.

\subsection{Section Vl's "Literary" Pole}

The SSL subdivision expanded between 1966 and the mid-1970s. While collaborations between Barthes and Goldmann permanently declined, the former collaborated increasingly often with Greimas. In 1966-1967, SSL included eight members (Table 6): Roland 
de huit membres (Tableau 6) : Roland Barthes, André Miquel et Georges Dumézil, le sinologue Alexis Rygaloff venu de la division " Histoire et géographie ", et Algirdas Julien Greimas, JeanClaude Gardin et Jacques Bertin, dont les enseignements étaient précédemment « hors division ».

\section{Tableau 6}

L'évolution de la division "Sémantique, sémiologie et linguistique " de la Vle Section de l'EPHE, de sa création en 1966-1967 à l'année académique 1975-1976

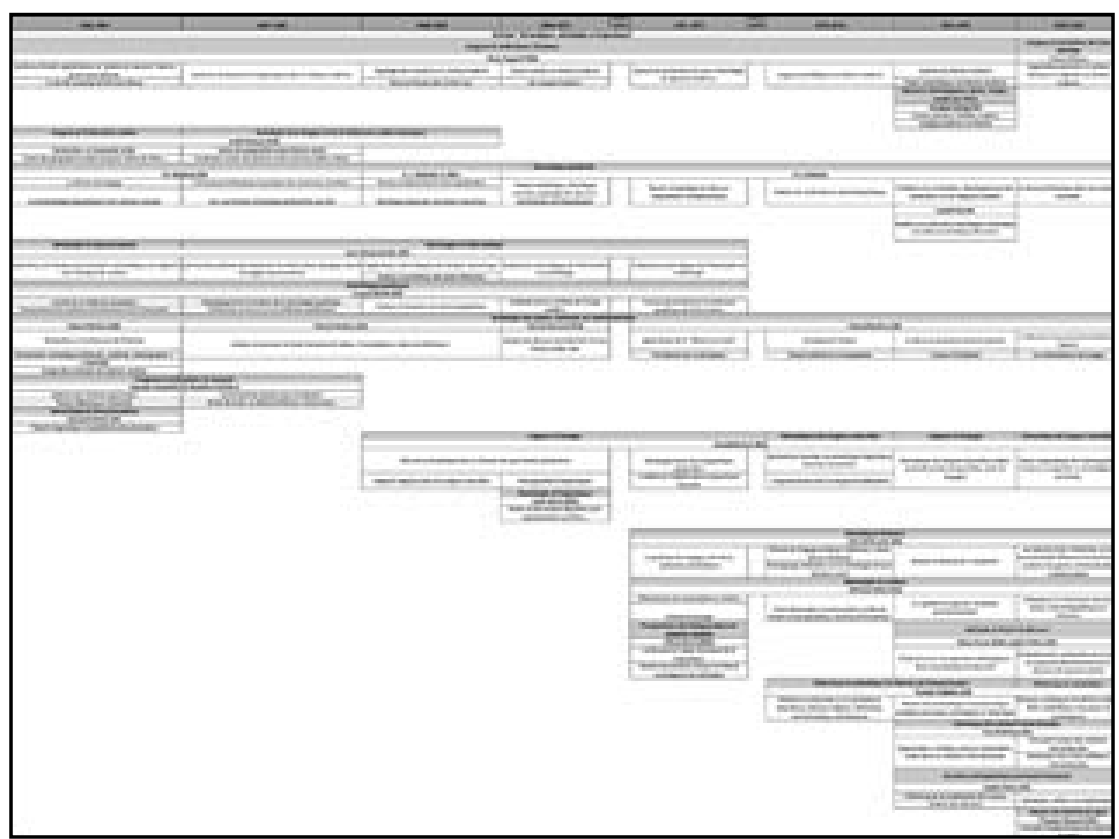

Note : les relevés d'enseignement n'étant pas disponibles pour les années 1970-1971 et 1972-1973, les espaces ont été laissés vacants. Source : Annuaires de la Vle section de l'EPHE.
Barthes, André Miquel and Georges Dumézil, sinologist Alexis Rygaloff, from the "History and geography" subdivision, Algirdas Julien Greimas, Jean-Claude Gardin, and Jacques Bertin, whose teachings were previously not affiliated with any of the clusters.

\section{Table 6}

The Evolution of the Semantics, Semiology and Linguistics (SSL) subivision at Section VI of the EPHE, from its creation in 1966-1967 to 1975-1976

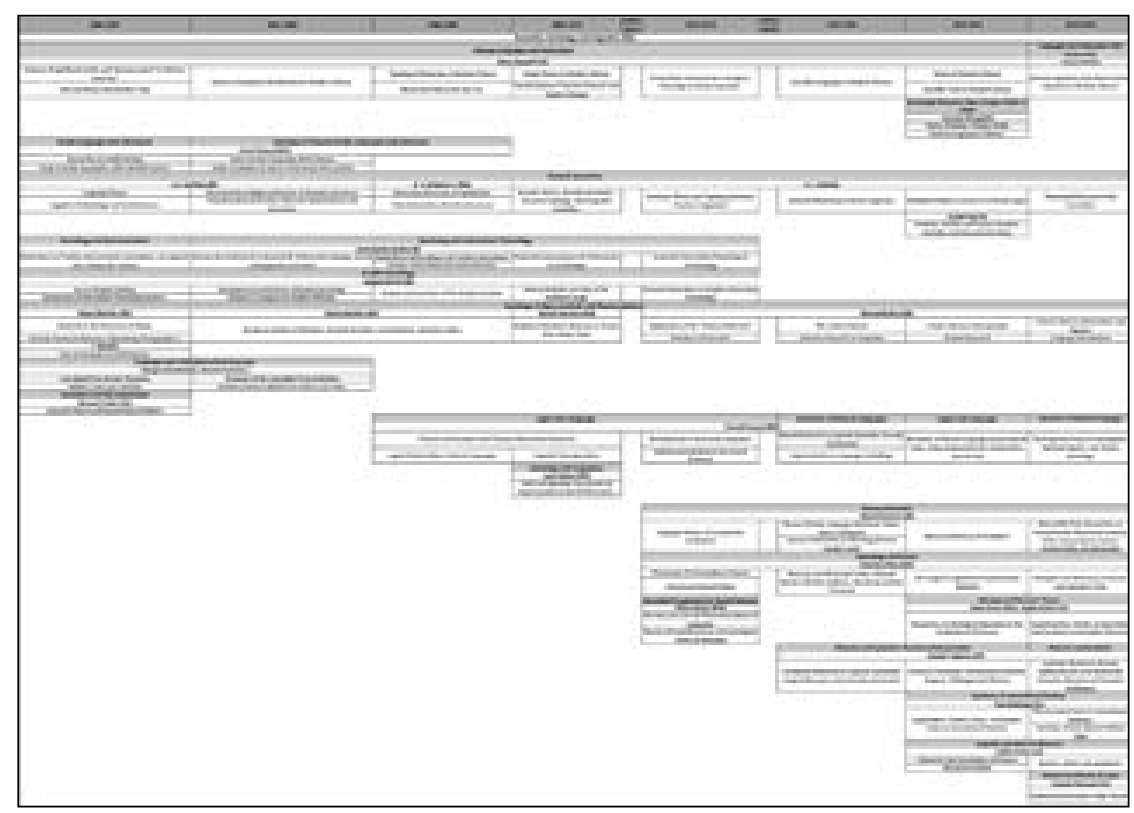

Note: As class reports are unavailable for the academic years 1970-1971 and 1972-1973 the corresponding columns have been left blank.

Source: Section VI Directories. 
Deux tendances principales sont visibles dans les premières années de la division. D'abord, la part croissante occupée par les questions littéraires : Barthes y consacre son séminaire à partir de 1967-1968, qui donne lieu à la publication de l'analyse sémiotique de Sarrasine de Balzac, S/Z (1970). Greimas, la même année, s'intéresse aux structures narratives, puis JeanClaude Gardin étudie l'application de systèmes de traitement automatique de l'information aux textes littéraires et Louis Marin analyse les relations image-texte. En 1969-1970, le remplacement de Roland Barthes par Gérard Genette, qui démarre ensuite son séminaire de "Sémiotique littéraire » renforce la focalisation sur la littérature. Maître de conférences à la Vle section à partir de 1967 et élu DE en 1972, Genette a alors déjà publié les deux premiers volumes des Figures $(1966,1969)$ et se prépare à quitter l'orbite de $T e l$ Quel pour créer la revue de théorie littéraire Poétique en 1970 avec Hélène Cixous et Tzvetan Todorov. Les nouveaux développements de la linguistique ne sont pas en reste, comme en témoignent les enseignements d'Eliséo Veron et de Sophie Fisher, de François Récanati et surtout d'Oswald Ducrot. Ensuite, on observe l'expression récurrente de la volonté de construire des approches théoriques générales des objets linguistiques, littéraires et artistiques appuyées sur la sémiologie, la sémiotique et la sémantique, également enseignées dans les EPRASS. Ainsi en 1966-1967, Rygaloff affirme que « c'est principalement au niveau de la théorie, et seulement de façon accessoire dans ses applications au chinois, qu'ont été abordés [...] les problèmes de définition et de conception qui se posent à propos des unités linguistiques de tous ordres ${ }^{27}$ ». Greimas cherche à " préciser le statut des théories du langage, ainsi que la nature et l'organisation de l'espace épistémologique qu'elles recouvrent ${ }^{28}$ ", et embrasse

27 Annuaire 1967-1968: 222.

28 Ibid. : 226
Two main trends stand out in the subdivision's early years. First, the increasing proportion taken up by literary themes: they were the subject of Barthes's seminar beginning in 1967-1968, which led to his semiotic analysis of Balzac's Sarrasine, S/Z (1970); the same year, Greimas examined narrative structures; then, JeanClaude Gardin studied the application of automated information processing systems to literary texts and Louis Marin analysed relations between images and texts. In 1969-1970, Roland Barthes was replaced by Gérard Genette, who launched a seminar on "Literary Semiotics," thus strengthening the focus on literature. A maître de conférences at Section VI in 1967, elected DE in 1972, Genette had by then already published the first two volumes of his Figures $(1966,1969)$ and was about to distance himself from Tel Quel and create the literary theory journal Poétique in 1970 alongside Hélène Cixous and Tzvetan Todorov. New developments in linguistics were not overlooked-being tackled on courses by Eliséo Veron and Sophie Fisher, François Récanati and, most importantly, Oswald Ducrot. There was a regularly reasserted effort to develop general theoretical approaches to linguistic, literary, and artistic objects drawing on semiology, semiotics, and semantics, which were also taught in the EPRASS. In 1966-1967, Rygaloff claimed that the "issues of definition and conception that arise regarding all types of linguistic unit have mainly been addressed in terms of theory, and only incidentally in terms of applications of the theory to Chinese ${ }^{28}$." Greimas sought to "specify the status of theories of language, as well as the nature and organization of the epistemological space they cover ${ }^{29}$," in the process encompassing a wide variety of possible applications of studies by "specialists, or semioticians looking to specialize ${ }^{30}$." A pole of specialists of

28 Annuaire 1967-1968: 222

29 Ibid: 226

30 Ibid. 
une importante variété d'applications possibles de travaux de " spécialistes, ou sémioticiens cherchant à se spécialiser ${ }^{29}$ ". C'est un pôle de spécialistes du langage qui se constitue, et qui apparaît, malgré sa faiblesse numérique par rapport à d'autres ensembles disciplinaires, relativement autonome ${ }^{30}$. La division SSL s'établit autour d'approches théoriques et méthodologiques similaires appliquées à des objets divers, alors que la sociologie de la littérature goldmannienne tentait au contraire de s'imposer comme spécialité à l'intérieur de la sociologie.

Les membres de la division SSL sont les éléments moteurs d'une tentative de renouvellement des études littéraires engagée autour du structuralisme et de la critique de l'enseignement littéraire dans le secondaire et le supérieur. Appuyées sur des appropriations variées de la linguistique structurale, du formalisme russe et de la psychanalyse, les théories littéraires élaborées dans ce groupe hétérogène se sont progressivement spécialisées sur l'analyse interne des textes. Le $\mathrm{n}^{\circ} 8$ de Communications consacré à l'analyse structurale des récits (1966), les travaux de Barthes, de Genette, de Todorov, ainsi que certains textes de Greimas diffusés bien au-delà de la $\mathrm{Vl}^{\mathrm{e}}$ section sont centraux dans cette évolution, permise par la refonte des études littéraires et renforcée par le développement des lettres modernes dans les années 1960 et 1970. Enfin, le groupe a bénéficié de la «pluralité des principes de hiérarchisation » (Bourdieu $1984: 150$ sq.) ayant cours dans les espaces académiques et intellectuels : relais médiatiques, alliances avec des avant-gardes littéraires qui ont associé les théories à une radicalité politique et esthétique, implication ponctuelle dans des

29 Ibid.

30 Godechot montre ainsi qu'entre 1971 et 1975 les membres de la division SSL sont relativement isolés - Barthes mis à part - et ne collaborent que peu avec des membres d'autres disciplines dans les jurys de thèse (Godechot $2011: 11)$ language was taking shape, appearing relatively autonomous even though it had fewer members than other disciplinary groups ${ }^{31}$. The SSL subdivision was built around similar theoretical and methodological approaches applied to varied objects, whereas the Goldmannian sociology of literature was trying to assert its place as a speciality within sociology.

The members of SSL were the driving force behind an attempt to bring about a renewal of literary studies around structuralism and the critique of literary teaching in secondary and higher education. Drawing on various appropriations of structural linguistics, Russian formalism, and psychoanalysis, the literary theories developed by this heterogeneous group progressively became specialized in the internal analysis of texts. The eighth issue of Communications on the structural analysis of narratives (1966), writings by Barthes, Genette, Todorov, as well as some works by Greimas that were spread far beyond Section VI were central to this evolution, made possible by the refashioning of literary studies and reinforced by the development of the lettres modernes discipline (French language and literature) in the 1960s and 1970s. Lastly, the group took advantage of the "plurality of rival principles of hierarchization" (Bourdieu 1984: 150 sq.) at work in academic and intellectual spaces: using media connections, forging alliances with literary avant-gardes that combined theory and political and aesthetic radicalism, occasionally participating in teaching initiatives, joining publishing bodies, and so on. The evolution of the SSL subdivision

31 Godechot shows that between 1971 and 1975, members of the SSLsubdivision were somewhat isolated-except for Barthes-and only collaborated with members from other disciplines in terms of doctoral adjudication (Godechot 2011: 11). 
initiatives pédagogiques, investissement d'instances éditoriales... L'évolution de la division SSL permet ainsi de faire plusieurs constats. D'abord celui du succès de l'initiative collective, appuyée sur une relative cohérence paradigmatique et sur un faisceau de cadres théoriques, méthodologiques et disciplinaires relativement proches, par opposition à l'héritage individuel qui caractérise la sociologie de la littérature goldmannienne. Ensuite celui de l'investissement de deux référentiels disciplinaires - la linguistique et les études littéraires - par opposition à la marginalisation de la sociologie de la littérature goldmannienne dans la sociologie. Enfin, l'absence initiale de structure disciplinaire propre à l'étude des objets linguistiques, littéraires et artistiques dans la $\mathrm{Vl}^{e}$ section a sans doute favorisé le passage d'un réseau diffus à un pôle constitué sur la base de proximités théoriques, académiques et sociales.

Ces oppositions entre les héritiers des premiers spécialistes de littérature à la $\mathrm{Vl}^{\mathrm{e}}$ section se sont un temps manifestées et retraduites sous différentes formes, notamment par des prises de position intellectuelles et des épisodes conflictuels. Pourtant, la génération des élèves de Barthes, Goldmann et Francastel respectivement Gérard Genette et Tzvetan Todorov, Jacques Leenhardt, Hubert Damisch - se détache de la sociologie et se rassemble à plus long terme au pôle lettres et arts qui s'institutionnalise dans l'EHESS, à la faveur des politiques de regroupement d'unités de recherches du CNRS. En sociologie, l'étude des arts et de la littérature s'institutionnalise également dans les décennies suivantes, tant du côté des laboratoires (Raymonde Moulin avait créé en 1983 le Centre de sociologie des arts, qui a ensuite intégré l'actuel Centre d'études sociologiques et politiques Raymond Aron) que des revues ou des associations de recherche, comme en témoigne la revue Sociologie de l'Art, créée en 1992 par le comité « Sociologie de l'art » de l'Association internationale suggests several observations. First, its collective initiative was a success, drawing on a relative paradigmatic consistency and on a range of fairly close theoretical, methodological, and discipline frameworks, at odds with the individual legacy characterizing the Goldmannian sociology of literature. Secondly, two disciplinary paths were pursued-linguistics and literary studies-whereas the Goldmannian sociology of literature was marginalized within the discipline of sociology. Lastly, the initial absence of a disciplinary structure specific to the study of linguistic, literary, and artistic objects in Section VI arguably facilitated the shift from a diffuse network to an established pole formed on the basis of theoretical, academic, and social connections.

For some time, oppositions between the inheritors of the early specialists of literature in Section VI manifested themselves under various forms, including intellectual stances and periods of conflict. Ultimately, the generation of the students of Barthes, Goldmann, and Francastel - respectively Gérard Genette and Tzvetan Todorov, and Jacques Leenhardt and Hubert Damisch-grew distant from sociology and in the longer term ended up rallying around the pole of scholars in literature and the arts that was institutionalized at the EHESS under the impetus of the policies aimed at merging CNRS research units. In sociology, the study of the arts and literature was also institutionalized in the following decades, both in laboratories (in 1983, Raymonde Moulin had created the Centre for the Sociology of the Arts, which then became a part of the Raymond Aron Centre for Sociological and Political Studies) and in journals and research groups-for instance with the journal Sociologie de l'Art, launched by the "Sociology of Art" committee of the International Association of French-Language Sociologists (AISLF) (Péquignot 2005). Over 
des sociologues de langue française (AISLF) (Péquignot 2005). Dans le même temps, la sociologie de la littérature d'inspiration bourdieusienne se développe à l'intérieur de la sociologie et dans un dialogue croissant, quoique parfois conflictuel, avec les études littéraires. Ces divisions et ces alliances, qui prennent leur sens dans des temporalités plus étendues que ce que la chronologie officielle de l'enseignement supérieur et de la recherche peut laisser entendre, soulignent s'il le fallait encore qu'il n'y a pas de création institutionnelle ex nihilo mais bien " des recyclages de traces de collectifs plus anciens, même si les créateurs sont portés à l'oublier » (Brian \& Jaisson $1988: 66$ )

\section{Conclusion}

On espère avoir montré comment certaines logiques de (re) configuration disciplinaire et de spécialisation peuvent se déployer dans un espace initialement dépourvu de divisions disciplinaires mais profondément marqué par les transformations des espaces académiques et intellectuels. L'évolution de la sociologie de la littérature de Goldmann semble pâtir de ces transformations et ne trouver sa place que dans les circuits internationaux propres à la spécialité. L'évolution de la philosophie, que nous n'avons pu traiter ici, participe de sa mise à l'écart. Pourtant, contre « l'illusion de l'autarcie " (Convert \& Heilbron $2005: 20$ ), c'est à la fois dans les disciplines et en dehors de celles-ci qu'il faut comprendre l'évolution des spécialités. La sociologie de la littérature, prise dans les logiques d'institutionnalisation de ses deux disciplines de tutelle, la sociologie et les études littéraires, en est une illustration.

Le développement de la sociologie de la littérature s'appuie sur un réseau structuré et hiérarchisé qui peut être vécu et défendu sur le même mode que le serait l'appartenance disciplinaire. L'émergence de la division SSL à la Vle section semble suivre un the same period, a Bourdieu-inspired strand of the sociology of literature developed within sociology, increasingly pursuing a dialogue with literary studies. These divisions and alliances, which acquired meaning over longer periods of time than what the official chronology of higher education and research may lead us to think, are a further reminder that there is no such thing as an ex nihilo institutional creation; rather there are "recyclings of traces of older collectives, even though creators are wont to forget about them" (Brian \& Jaisson 1988: 66).

\section{Conclusion}

This article has strived to show how rationales of disciplinary (re) configuration and specialization may unfold in a space initially devoid of divisions by discipline but deeply affected by the transformations of academic and intellectual spaces. The evolution of Goldmann's sociology of literature appears to have suffered from these transformations - only finding a place in the speciality's own international channels. The evolution of philosophy, which was not within the purview of this paper, contributed to its marginalization. Yet, to avoid "illusory self-sufficiency" (Convert \& Heilbron 2005: 20 ), the evolution of specialities should be understood both within the disciplines and outside them. The sociology of literature is an illustration of this, as it was affected by the institutionalization process of two disciplines-sociology and literary studies.

The development of the sociology of literature drew on a structured and hierarchized network that was in some ways experienced and defended as a disciplinary affiliation would have been. The emergence of the SSL subdivision in Section VI appears to have 
mouvement inverse. Elle est a minima paradoxale : elle légitime et promeut de nouvelles approches et une spécialisation sur l'objet littéraire, qui ne sont pourtant pas uniquement le fait de spécialistes de littérature. Mais là encore, la réinscription de ce - tout petit groupe de producteurs intellectuels dans les évolutions plus amples des champs académiques et intellectuels, et la prise en compte de leurs productions fournissent des éléments d'explications sur le rôle capital joué par le référent disciplinaire dans leur succès en France et à l'étranger. En effet, la prégnance de la question de la « littérarité » dans leurs travaux - principe organisateur de la littérature s'il en est - comme le fait que les membres littéraires de la division SSL se consacrent à la production théorique et métathéorique, relativement éloignée de questionnements pédagogiques, s'ajoutent au prestige accordé à la théorie dans les sciences humaines et sociales. La dynamique de ce groupe se rapproche dès lors bien de celle de la « régression vers la pureté professionnelle » identifiée par Andrew Abbott (Abbott 2001: 146), pour qui celle-ci s'articule nécessairement avec la diffusion d'approches concurrentielles de l'objet d'étude tout en plaçant ses agents en haut de la hiérarchie de la discipline.

Lucile Dumont

École des hautes études en sciences sociales/Centre européen de sociologie et de science politique-Centre de sociologie européenne (EHESS, CESSP-CSE) followed an inverse trend. It was paradoxical to the extent that it legitimized and promoted new approaches and a specialization in literary subjects that did not only rely on specialists of literature. In this case, too, the journey of this very small group of intellectual producers stands to gain from being envisioned within broader trends in the academic and intellectual fields. Likewise, their outputs give us some indication as to the crucial role played by the disciplinary reference in their domestic and international success. Indeed, the importance of the question of "literarity" in their studiesthe essential organizing principle of literature-and the fact that the literary members of the SSL subdivision focused on theoretical and meta-theoretical outputs that were relatively far removed from pedagogic concerns gave them the prestige attributed to theory in the human and social sciences. The dynamic of this group is in that sense indeed a case of "regression into professional purity" as pinpointed by Andrew Abbott (Abbott 2001: 146), who argued that it was necessarily combined with the diffusion of competing approaches to the object of study and the placement of its agents at the top of the discipline's hierarchy.

Lucile Dumon

École des hautes études en sciences sociales/Centre européen de sociologie et de science politique-Centre de sociologie européenne (EHESS, CESSP-CSE) 
Annexe

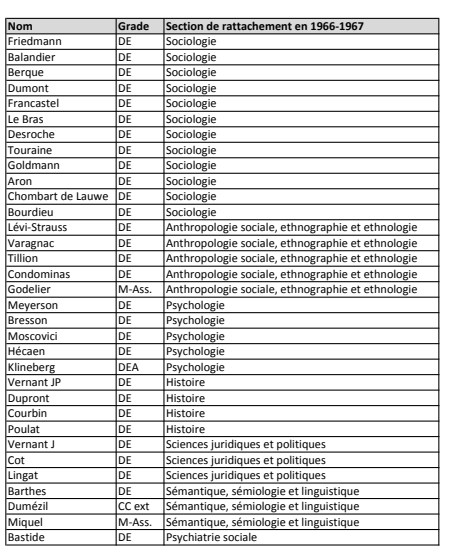

Appendix

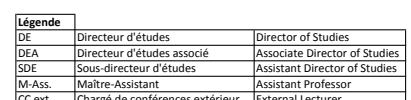

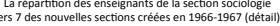

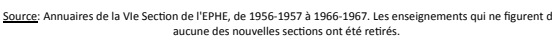

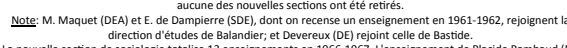

(6)

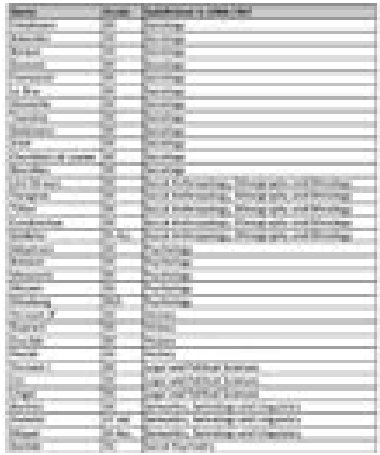

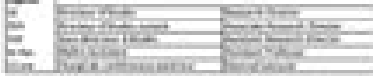

$-1+10=$

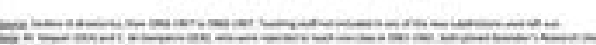

= 


\section{Références bibliographiques}

Аввотт Andrew (2001). Chaos of Disciplines. Chicago, Chicago University Press.

BARTHES Roland [1960]. « Histoire et littérature : à propos de Racine 》. In BARTHES Roland (2002). CEuvres Complètes I, 1942-1961. Paris, Seuil : 175-194.

Ben-DaVID Joseph \& Collins Randall (1997)[1966]. « Les facteurs sociaux dans la genèse d'une nouvelle science. Le cas de la psychologie ». In BEN-DAVID Joseph, Éléments d'une sociologie historique des sciences. Paris, PUF : 65-92.

BOURDIEU Pierre (1966). «Champ intellectuel et projet créateur ». Les Temps Modernes, $246:$ 865-906.

BOURDieu Pierre (1971). « Le marché des biens symboliques ». L’Année sociologique, $22: 49-126$.

BOURDIEU Pierre (1975). « L'invention de la vie d'artiste ». Actes de la recherche en sciences sociales, $2: 6793$.

BouRdieu Pierre (1980). Questions de sociologie. Paris, Minuit.

Bourdieu Pierre (1984a). Homo Academicus. Paris, Minuit.

BOURDIEU Pierre (1984b). « Le champ littéraire. Préalables critiques et principes de méthode ». Lendemains, $36: 5-20$.

\section{References}

Аввотт Andrew (2001). Chaos of Disciplines. Chicago, Chicago University Press.

BARTHES Roland (1964) [1960]. On Racine. English translation by Richard Howard. New York, Hill and Wang.

BEN-DAVID Joseph \& Collins Randall (1966). "Social Factors in The Origins of a New Science: The Case of Psychology." American Sociological Review, 31(4): 451-465.

BOURDIEU Pierre (1969) [1966]. "Intellectual Field and Creative Project." English translation by Sian France. Social science information, 8(2): 89119.

BOURDIEU Pierre (1993) [1971]. "The Market of Symbolic Goods." In BouRdieu Pierre. The Field of Cultural Production: Essays on Art and Literature. New York, Columbia University Press: 112-141.

BouRdieu Pierre (1987) [1975]. "The Invention of the Artist's Life.” English translation by Erec R. Koch. Yale French Studies, 73: 75-103.

BOURDIEU Pierre (1994) [1980]. Sociology in Question. English translation by Richard Nice. London, Sage.

BouRdieu Pierre (1988) [1984]. Homo Academicus. English translation by Peter Collier. Cambridge, Polity Press.

BOURDIEU Pierre (1996) [1992]. The Rules of Art. Genesis and Structure of the Literary Field. English translation by Susan Emmanuel. Cambridge, Polity Press. 
BOURDIEU Pierre (1985). « Existe-t-il une littérature belge ? Limites d'un champ et frontières politiques ». Études de lettres, 4 : 3-6.

BOURDIEU Pierre (1991). "Le champ littéraire 》. Actes de la recherche en sciences sociales, $89: 3-46$.

BouRdieu Pierre (1992). Les Règles de l'art. Genèse et structure du champ littéraire. Paris, Seuil.

Bourdieu Pierre (2001). Science de la science et réflexivité. Paris, Seuil.

BrIAN Éric \& JaISSON Marie (1988). "Unités et identités : Notes sur l'accumulation scientifique ». Actes de la recherche en sciences sociales, $74: 6675$.

Callu Agnès (2011). Gaëtan Picon, 1915-1976 : esthétique et culture. Paris, Honoré Champion.

CARDOn-Quint Clémence (2015). Des lettres au français. Une discipline à l'heure de la démocratisation (1945-1981). Rennes, Presses universitaires de Rennes.

Chevalier Jean-Claude \& EnCReVÉ Pierre (2006). Combats pour la linguistique de Martinet à Kristeva : essai de dramaturgie épistémologique. Lyon, ENS Éditions.

Compagnon Antoine (1983). La Troisième République des lettres : de Flaubert à Proust. Paris, Seuil.

CONVERT Bernard \& HEILBRON Johan (2005). « La réinvention américaine de la sociologie économique ». L'Année sociologique, 55 : 329-364.

DiRkX Paul (2000). Sociologie de la littérature. Paris, Armand Colin.
BOURDIEU Pierre (1985). "Existe-t-il une littérature belge? Limites d'un champ et frontières politiques". Études de lettres, $4: 3-6$.

BOURDIEU Pierre (1991). "Le champ littéraire". Actes de la recherche en sciences sociales, $89:$ 3-46.

Bourdieu Pierre (1992). Les Règles de l'art. Genèse et structure du champ littéraire. Paris, Seuil.

BOURDIEU Pierre (2004) [2001]. Science of Science and Reflexivity. English translation by Richard Nice. Chicago, University of Chicago Press.

BrIAN Éric \& JAISSON Marie (1988). "Unités et identités: Notes sur l'accumulation scientifique." Actes de la recherche en sciences sociales, 74: 66-75.

Callu Agnès (2011). Gaëtan Picon, 1915-1976: esthétique et culture. Paris, Honoré Champion.

CARDON-Quint Clémence (2015). Des lettres au français. Une discipline à l'heure de la démocratisation (1945-1981). Rennes, Presses universitaires de Rennes.

Chevalier Jean-Claude \& EnCrevé Pierre (2006). Combats pour la linguistique de Martinet à Kristeva : essai de dramaturgie épistémologique. Lyon, ENS Éditions.

Compagnon Antoine (1983). La Troisième République des lettres: de Flaubert à Proust. Paris, Seuil.

Convert Bernard \& HeILBRon Johan (2007) [2005]. "Where did the New Economic Sociology come from?". English translation by Amy Jacobs. Theory and society, 36(1): 31-54.

DIRKX Paul (2000). Sociologie de la littérature. Paris, Armand Colin. 
DORMOY-RAJRAMANAN Christelle (2017). « L'institutionnalisation de domaines d'études pluridisciplinaires autour de 68 ». Revue d'anthropologie des connaissances, 11(3) : 351-377.

DROUARD Alain (1982). «Réflexions sur une chronologie : le développement des sciences sociales en France de 1945 à la fin des années soixante ». Revue française de sociologie, 23(1) : 55-85.

FEUERHAHn Wolf (dir.) (2017). La politique des chaires au Collège de France. Paris, Collège de France/ Les Belles lettres.

Genette Gérard (1966). Figures. Paris, Seuil.

Genette Gérard (1969). Figures II. Paris, Seuil.

GODECHOT Olivier (2011). « La formation des relations académiques au sein de l'EHESS ». Histoire et mesure, 26(2) : 223-260.

Goldmann Lucien (1955). Le Dieu caché. Paris, Gallimard.

HAUCHECORNE Mathieu (2011). « Le polycentrisme des marges. Les "filières" belge et québécoise d'importation de la philosophie politique étasunienne contemporaine en France ». Histoire@Politique 15 : 90-109.

HAUCHECORNE Mathieu (2016). « Essor et disciplinarisation des sciences sociales ». In JeANPIERRE Laurent, Charle Christophe (dir.). La vie intellectuelle en France, II. Paris, Seuil : 565-589.

HeILBRON Johan (2004). «A Regime of Disciplines : Toward a Historical Sociology of Disciplinary Knowledge ». In CAMIC Charles, JoAs Hans (dir.).
DORMOY-RAJRAMANAN Christelle (2017). "L'institutionnalisation de domaines d'études pluridisciplinaires autour de 68." Revue d'anthropologie des connaissances, 11(3): 351-377.

DrouARD Alain (1982). "Réflexions sur une chronologie: le développement des sciences sociales en France de 1945 à la fin des années soixante." Revue française de sociologie, 23(1): 55-85.

Feuerhahn Wolf (ed.) (2017). La Politique des chaires au Collège de France. Paris, Collège de France/Les Belles Lettres.

Genette Gérard (1966). Figures. Paris, Seuil.

GenetTE Gérard (1982) [1966-1969]. Figures of Literary Discourse. English translation by Alan Sheridan. New York, Columbia University Press.

GODECHOT Olivier (2011). "La formation des relations académiques au sein de l'EHESS." Histoire et mesure, 26(2): 223-260.

Goldmann Lucien (1964) [1955]. The Hidden God: a Study of Tragic Vision in the Pensees of Pascal and the Tragedies of Racine. English translation by Philip Thody. London, Routledge.

HAUCHECORNE Mathieu (2011). "Le polycentrisme des marges. Les 'filières' belge et québécoise d'importation de la philosophie politique étasunienne contemporaine en France." Histoire@Politique 15: 90-109.

HAUCHECORNE Mathieu (2016). "Essor et disciplinarisation des sciences sociales." In JeAnPIERRE Laurent, ChaRle Christophe (eds). La Vie intellectuelle en France, II. Paris, Seuil: 565-589.

HEILBRON Johan (2004). "A Regime of Disciplines: Toward a Historical Sociology of Disciplinary Knowledge." In CAMIC Charles, JoAs Hans (eds.). 
The Dialogical Turn :New Roles for Sociology in the Postdisciplinary Age. Lanham, Rowman \& Littlefield : 23-42.

Heilbron Johan (2015). French Sociology. Ithaca and London, Cornell University Press.

KARADY Victor (1976). "Durkheim, les sciences sociales et l'Université : bilan d'un semi-échec ». Revue française de sociologie, 17(2) : 267-311.

KaUpPI Niilo (1996). «Approach or Discipline ? The Field of Semiology/ Semiotics in France in the 1960s and 1970s ". The European Legacy, $1(4): 1484-1489$

LAMY Jérôme \& SAINT-MARTIN Arnaud (2011). « Pratiques et collectifs de la science en régimes Note critique ». Revue d'histoire des sciences, 64(2) : 377-389.

LEPENIES Wolf (1990). Les Trois Cultures. Entre science et littérature, l'avènement de la sociologie. Paris, Éditions de la Maison des sciences de l'homme.

MARTIN Jean-Pierre (dir.) (2010). Bourdieu et la littérature. Nantes, Éditions Cécile Defaut.

MATONTI Frédérique (2005). Intellectuels communistes. Essai sur l'obéissance politique. La Nouvelle Critique (1967-1980). Paris, La Découverte.

MAzon Brigitte (1988). Aux origines de l'École des hautes études en sciences sociales : le rôle du mécénat américain 1920-1960. Paris, Cerf.

Pequignot Bruno (2005). « La sociologie de l'art et de la culture en France : un état des lieux ». Sociedade e Estado 20(2).
The Dialogical Turn:New Roles for Sociology in the Postdisciplinary Age. Lanham, Rowman \& Littlefield: 23-42.

HeILBRon Johan (2015). French Sociology. Ithaca and London, Cornell University Press.

KARADY Victor (1976). "Durkheim, les sciences sociales et l'Université bilan d'un semi-échec." Revue française de sociologie, 17(2): 267-311.

KaUPPI Niilo (1996). "Approach or Discipline? The Field of Semiology/ Semiotics in France in the 1960s and 1970s." The European Legacy, 1(4): 1484-1489.

LAMY Jérôme \& SAINT-MARTin Arnaud (2011). "Pratiques et collectifs de la science en régimes Note critique." Revue d'histoire des sciences, 64(2): 377-389.

LePENIES Wolf (1990). Les Trois Cultures. Entre science et littérature, l'avènement de la sociologie. Paris, Éditions de la Maison des sciences de l'homme.

MARTIN Jean-Pierre (ed.) (2010). Bourdieu et la littérature. Nantes, Éditions Cécile Defaut.

MatonTI Frédérique (2005). Intellectuels communistes. Essai sur l'obéissance politique. La Nouvelle Critique (1967-1980). Paris, La Découverte.

Mazon Brigitte (1988). Aux origines de l'École des hautes études en sciences sociales: le rôle du mécénat américain 1920-1960. Paris, Cerf.

Pequignot Bruno (2005). "La sociologie de l'art et de la culture en France: un état des lieux." Sociedade e Estado 20(2). 
PICARD Jean-François (1990). La République des savants : la recherche française et le CNRS. Paris, Flammarion.

PopA loana (2015). " Aires culturelles et recompositions (inter) disciplinaires : la $6^{e}$ section de l'EPHE et les études sur l'espace russe, soviétique et est-européen ". Actes de la recherche en sciences sociales, $210: 60-81$.

ReVel Jacques \& WACHTEL Nathan (dir.) (1996). Une école pour les sciences sociales : de la Vle Section à l'École des hautes études en sciences sociales. Paris, Cerf/ Éditions de l'EHESS.

SamoYault Tiphaine (2015). Roland Barthes. Paris, Seuil.

SAPIRO Gisèle (2004). "Défense et illustration de "I'honnête homme". Les hommes de lettres contre la sociologie ». Actes de la recherche en sciences sociales, $153: 11-27$.

SAPIRO Gisèle (2014). La Sociologie de la littérature. Paris, La Découverte.

SAPIRO Gisèle (2017). « Champ ». Politika. [En ligne]. https://www.politika. io/fr/notice/champ [consulté le 8 décembre 2017].

SoULIÉ Charles (2012). « La recomposition des facultés et disciplines dans l'Université française des années 1960 ». In SouLIÉ Charles (dir.). Un mythe à détruire ? Vincennes fac ouverte à tous. Saint-Denis, Presses universitaires de Vincennes, 31-60.

VAN NUIJS Laurence (2007). «La sociologie de la littérature selon Escarpit. Structure, évolution et ambiguittés d'un programme de recherche ". Poétique 149 : 107-127.
PICARD Jean-François (1990). La République des savants: la recherche française et le CNRS. Paris, Flammarion.

POPA loana (2015). "Aires culturelles et recompositions (inter)disciplinaires: la $6^{e}$ section de l'EPHE et les études sur l'espace russe, soviétique et esteuropéen." Actes de la recherche en sciences sociales, 210: 60-81.

ReVEL Jacques \& WACHTEL Nathan (eds.) (1996). Une école pour les sciences sociales: de la Vle Section à l'École des hautes études en sciences sociales. Paris, Cerf/ Éditions de l'EHESS.

SAmOYAULt Tiphaine (2015). Roland Barthes. Paris, Seuil.

SAPIRO Gisèle (2004). "Défense et illustration de 'l'honnête homme'. Les hommes de lettres contre la sociologie." Actes de la recherche en sciences sociales, 153: 11-27.

SAPIRO Gisèle (2014). La Sociologie de la littérature. Paris, La Découverte.

SAPIRO Gisèle (2017). "Champ." Politika. [On line]. https://www.politika.io/ fr/notice/champ [accessed on 8 december 2017].

SouLlé Charles (2012). "La recomposition des facultés et disciplines dans l'Université française des années 1960." In SoULIÉ Charles (ed.). Un mythe à détruire? Vincennes fac ouverte à tous. Saint-Denis, Presses universitaires de Vincennes, 31-60.

VAN NUIJS Laurence (2007). "La sociologie de la littérature selon Escarpit. Structure, évolution et ambiguïtés d'un programme de recherche." Poétique 149: 107-127. 